\title{
Targeting the Calcium Signalling Machinery in Cancer
}

\author{
Jason I. E. Bruce 1,* and Andrew D. James ${ }^{2}$ \\ 1 Division of Cancer Sciences, School of Medical Sciences, Faculty of Biology, Medicine and Health, \\ University of Manchester, Manchester M13 9PT, UK \\ 2 Department of Biology, University of York, Heslington, York YO10 5DD, UK; andrew.james@york.ac.uk \\ * Correspondence: jason.bruce@manchester.ac.uk; Tel.: +44-(0)-161-275-5484
}

Received: 29 June 2020; Accepted: 8 August 2020; Published: 20 August 2020

\begin{abstract}
Cancer is caused by excessive cell proliferation and a propensity to avoid cell death, while the spread of cancer is facilitated by enhanced cellular migration, invasion, and vascularization. Cytosolic $\mathrm{Ca}^{2+}$ is central to each of these important processes, yet to date, there are no cancer drugs currently being used clinically, and very few undergoing clinical trials, that target the $\mathrm{Ca}^{2+}$ signalling machinery. The aim of this review is to highlight some of the emerging evidence that targeting key components of the $\mathrm{Ca}^{2+}$ signalling machinery represents a novel and relatively untapped therapeutic strategy for the treatment of cancer.
\end{abstract}

Keywords: calcium signalling; cancer; cancer hallmarks; TRP channels; CRAC; Orai; STIM; PMCA; SERCA; SPCA; IP3R; cell death; cell proliferation; cell migration; invasion; metastasis

\section{Introduction}

The major hallmarks of the cancer phenotype include limitless replicative capacity, self-sufficiency of growth and/or insensitivity of anti-growth signals, resistance to apoptosis, tissue invasion, and angiogenesis [1]. The vast majority of mainstay chemotherapeutic anti-cancer drugs target DNA replication (etoposide/gemcitibine), DNA/RNA synthesis (paclitaxel), DNA damage (doxorubicin), and growth factor receptor (GFR) signalling (Iressa, erlotinib) [2]. These all have the desired effects of stopping cells from dividing or triggering cell death. However, cytosolic $\mathrm{Ca}^{2+}$ and the components of the $\mathrm{Ca}^{2+}$ signalling machinery have critical roles in the regulation of all the above hallmark processes that underlie the cancer phenotype (Figure 1).

It is thus surprising that none of the current mainstay cancer chemotherapy drugs target the $\mathrm{Ca}^{2+}$ signalling machinery. This may well change in the future, especially since the recent discovery of the molecular identity of novel $\mathrm{Ca}^{2+}$ channels (e.g., Orai1 and numerous members of the transient receptor protein (TRP) family) and key regulatory proteins (e.g., stromal interacting molecule (STIM) and secretory pathway ATPase (SPCA)). Emerging evidence shows that these proteins have an increasingly important role in the numerous hallmark processes underlying the cancer phenotype, and thus offer a rich tapestry of novel putative therapeutic targets. Moreover, the cell surface expression of some of these $\mathrm{Ca}^{2+}$ channels and transporters makes them highly accessible to novel drugs or even antibody therapy. However, it is also important to note that the versatility and ubiquitous nature of $\mathrm{Ca}^{2+}$ signalling proteins means that targeting them with novel therapeutics would likely produce unacceptable adverse effects regardless of their specificity. Therefore, the ideal strategy is to target $\mathrm{Ca}^{2+}$ channels, or regulatory proteins, that are either uniquely expressed or their expression results in an entirely new function in cancer cells. This review will thus focus on candidates that fulfil some of these important criteria. 


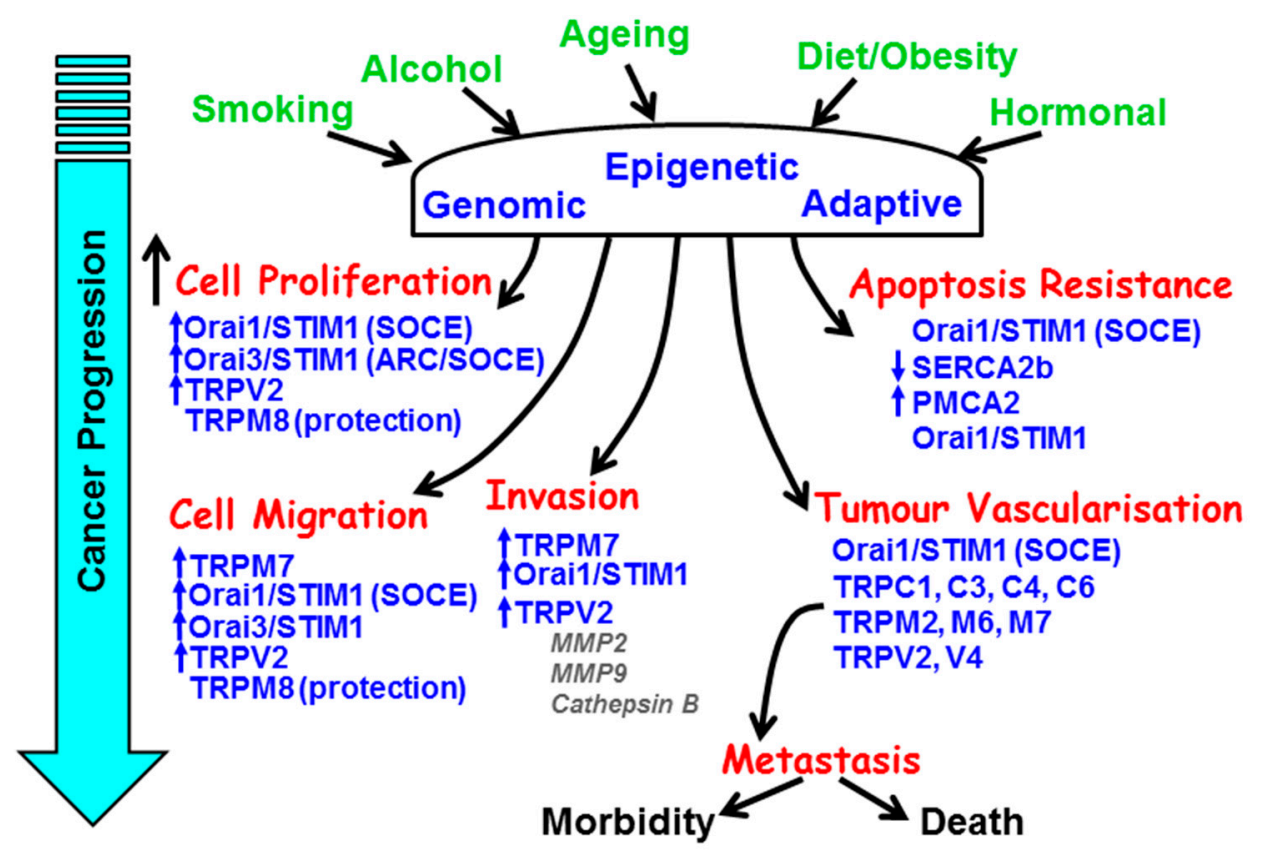

Figure 1. The remodelling of key components of the $\mathrm{Ca}^{2+}$ signalling machinery responsible for the hallmark processes of cancer during cancer progression. The major causes and risk factors of cancer induce genomic, epigenetic, and adaptive changes in key $\mathrm{Ca}^{2+}$ transporters responsible for the increase in cell proliferation, resistance to apoptosis, cellular migration and invasion, and tumour vascularisation.

\section{The Versatility of $\mathrm{Ca}^{2+}$ Signalling}

Cytosolic calcium $\left(\mathrm{Ca}^{2+}\right)$ is arguably the most important cell signal in biology, controlling diverse cellular process from the very beginning of cell life through to cell death and almost everything in between. This is achieved because $\mathrm{Ca}^{2+}$ signals come in different shapes, both in time and space, and are regulated by a diverse repertoire of $\mathrm{Ca}^{2+}$ channels, transporters, pumps (ATPases), and binding proteins, collectively known as the $\mathrm{Ca}^{2+}$ signalling machinery [3]. Key components of the $\mathrm{Ca}^{2+}$ signalling machinery work in concert to generate complex spatiotemporal patterns of $\mathrm{Ca}^{2+}$ signalling, such as $\mathrm{Ca}^{2+}$ oscillations, $\mathrm{Ca}^{2+}$ waves, spatially restricted $\mathrm{Ca}^{2+}$ spikes, and sustained global $\mathrm{Ca}^{2+}$ signals. These different spatiotemporal patterns of $\mathrm{Ca}^{2+}$ signalling can differentially encode diverse physiological processes, from cell division, transcription and differentiation, cellular contractility and motility, to fluid and protein secretion, and ultimately cell death [3]. Importantly, different types of $\mathrm{Ca}^{2+}$ signal can activate diametrically opposed cellular responses within the same cell. For example, global Ca ${ }^{2+}$ waves control the contraction of smooth muscle cells, whereas localised $\mathrm{Ca}^{2+}$ release specifically activates $\mathrm{Ca}^{2+}$-dependent $\mathrm{K}^{+}$channels, hyperpolarisation, and the consequent smooth muscle relaxation [4]. Moreover, the temporal properties of $\mathrm{Ca}^{2+}$ signalling convey important information. For example, the frequency of $\left[\mathrm{Ca}^{2+}\right]_{i}$ oscillations can differentially regulate gene transcription, and thus cell fate decisions, in T lymphocytes $[5,6]$.

\section{The Calcium Signalling Machinery}

The $\mathrm{Ca}^{2+}$ signalling machinery can be broadly categorised into those that elevate cytosolic $\mathrm{Ca}^{2+}$ (such as $\mathrm{Ca}^{2+}$ entry channels and intracellular $\mathrm{Ca}^{2+}$ release channels) and those that reduce cytosolic $\mathrm{Ca}^{2+}$ (such as $\mathrm{Ca}^{2+}$ pumps, $\mathrm{Ca}^{2+}$ transporters, and $\mathrm{Ca}^{2+}$-binding proteins). Intracellular $\mathrm{Ca}^{2+}$ release channels primarily include inositol 1,4,5-trisphosphate $\left(\mathrm{IP}_{3}\right.$ )-gated $\mathrm{Ca}^{2+}$ channels (also known as $\mathrm{IP}_{3}$ receptors $\left.\left(\mathrm{IP}_{3} \mathrm{Rs}\right)\right)$ and ryanodine receptors (RyRs), both expressed on the endoplasmic reticulum or sarcoplasmic reticulum. Both $\mathrm{IP}_{3} \mathrm{Rs}$ and RyRs can be gated by $\mathrm{Ca}^{2+}$ and contribute to $\mathrm{Ca}^{2+}$ induced $\mathrm{Ca}^{2+}$ release (CICR), which is important for amplifying $\mathrm{Ca}^{2+}$ signals $[7,8]$. Moreover, $\mathrm{IP}_{3} \mathrm{Rs}$ are inhibited by high $\mathrm{Ca}^{2+}$ concentration and represent the intrinsic oscillatory mechanism in many non-excitable 
cells $[7,8]$. Additional $\mathrm{Ca}^{2+}$ release channels have been shown to be expressed on other organelles such as lysosomes and secretory vesicles, gated by nicotinic acid adenine dinucleotide (NAADP) [9].

$\mathrm{Ca}^{2+}$ entry channels can be categorised into voltage-operated $\mathrm{Ca}^{2+}$ channels (VOCCs) activated by changes in membrane potential (e.g., L, T, N, and P/Q-type $\mathrm{Ca}^{2+}$ channels), ligand-gated $\mathrm{Ca}^{2+}$ channels (e.g., glutamate-gated N-Methyl D-glutamate (NMDA) receptors, ATP-gated purinergic P2X receptors), store operated $\mathrm{Ca}^{2+}$ entry channels (SOCE), and transient receptor potential (TRP) family of ion channels. Store-operated $\mathrm{Ca}^{2+}$ entry (SOCE) channels, otherwise known as $\mathrm{Ca}^{2+}$ release-activated $\mathrm{Ca}^{2+}$ channels (CRAC) or capacitative $\mathrm{Ca}^{2+}$ entry (CCE), are activated following depletion of the $\mathrm{ER} / \mathrm{SR} \mathrm{Ca}{ }^{2+}$ store and have been studied extensively since they were first described by Jim Putney during the early 1980s [10]. However, the molecular mechanism underlying SOCE remained elusive for over 20 years until the discovery of two important proteins, stromal interacting molecule (STIM) and CRACM (CRAC modulators), the latter of which later became known as Orai, named after the keeper of heaven's gate in Greek mythology [11,12] (Box 1).

Box 1. Store-Operated $\mathrm{Ca}^{2+}$ Entry (SOCE).

- $\quad$ SOCE consists of ER STIM1 and plasma membrane Orai1 [11,12]

- $\quad$ STIM1 consists of an EF hand which senses ER store depletion [12]

- $\quad$ Orai1 represents the pore-forming subunit of SOCE [13]

- $\quad$ ER store depletion triggers STIM1 oligomerization

- $\quad$ STIM1 oligomers activate $\mathrm{Ca}^{2+}$ entry through Orai1 channels

- SOCE channels consist of either Orai1 homotetramers or Orai1-Orai3 heterotetramers

The transient receptor potential (TRP) channels, named after the Drosophila mutants with a defective visual transduction system (transient light-induced photoreceptor depolarisation response), represent a large and diverse family of $\mathrm{Ca}^{2+}$-permeable, non-selective ion channels [14]. TRP channels are subdivided into TRPC (TRPC1-C7), TRPV (TRPV1-6), TRPM (TRPM1-8) and the more obscure families of muculipins (TRPML), polycystins (TRPP1-2), ANKTM, and the list continues to grow [14]. TRP channels function primarily as cellular sensors of the environment. This includes temperature (TRPV1-4, TRPM8), TRPV1 senses heat and capsaicin [15] and TRPM8 senses cold and menthol); osmolality/pain (TRPV4); pheromone sensing in rodents (mTRPC2 [16]); redox/metabolism (TRPM2 [17]); and mechanical forces, cell volume, membrane stretch, and ATP depletion (TRPM7).

$\mathrm{Ca}^{2+}$ clearance pathways primarily include the ATP-driven $\mathrm{Ca}^{2+}$ pumps found on the plasma membrane (plasma membrane $\mathrm{Ca}^{2+}$ ATPase, PMCA) [18], sarco/endoplasmic reticulum (sarco/endoplasmic reticulum $\mathrm{Ca}^{2+}$ ATPase, SERCA) and golgi apparatus or secretory pathway (secretory pathway $\mathrm{Ca}^{2+}$ ATPase, SPCA) [19]. Additional $\mathrm{Ca}^{2+}$ clearance pathways include the $\mathrm{Na}^{+} / \mathrm{Ca}^{2+}$ exchanger (NCX) [20], which is driven by the inward electrochemical $\mathrm{Na}^{+}$gradient/membrane potential, and the mitochondrial $\mathrm{Ca}^{2+}$ uniporter (MCU) responsible for $\mathrm{Ca}^{2+}$ uptake into the mitochondria [21].

\section{4. $\mathrm{Ca}^{2+}$ Signalling in Key Cancer Processes}

\subsection{Cell Proliferation}

$\mathrm{Ca}^{2+}$ signalling can activate several key signalling pathways and transcription factors that control cell proliferation and the cell cycle (Figure 2). Most notably, these include the transcription factors, nuclear factor of activated T cells (NFAT) [22], Oct/OAP, NFkB [5,6], cAMP response element-binding protein (CREB) [23], immediate early genes (FOS, JUN, and MYC) [24,25], as well as activation of the Ras-extracellular-signal-regulated kinase (Ras-ERK) pathway [26]. Importantly, many of these $\mathrm{Ca}^{2+}$-dependent effectors can be differentially regulated by specific spatiotemporal $\mathrm{Ca}^{2+}$ signals (see Figure 2). Localised $\mathrm{Ca}^{2+}$ entry can specifically and efficiently activate Ras-ERK pathways via $\mathrm{Ca}^{2+} /$ calmodulin (CaM) and guanine nucleotide exchange factors (GEFs) $[27,28]$. In addition, 
the frequency of $\mathrm{Ca}^{2+}$ oscillations can differentially regulate different transcription factors [5,6] and Ras/ERK pathways, via the Ras-guanine activating proteins (GAPs), CAPRI, and RASAL [29,30]. These are all important steps in the control of cell proliferation (Figure 2).

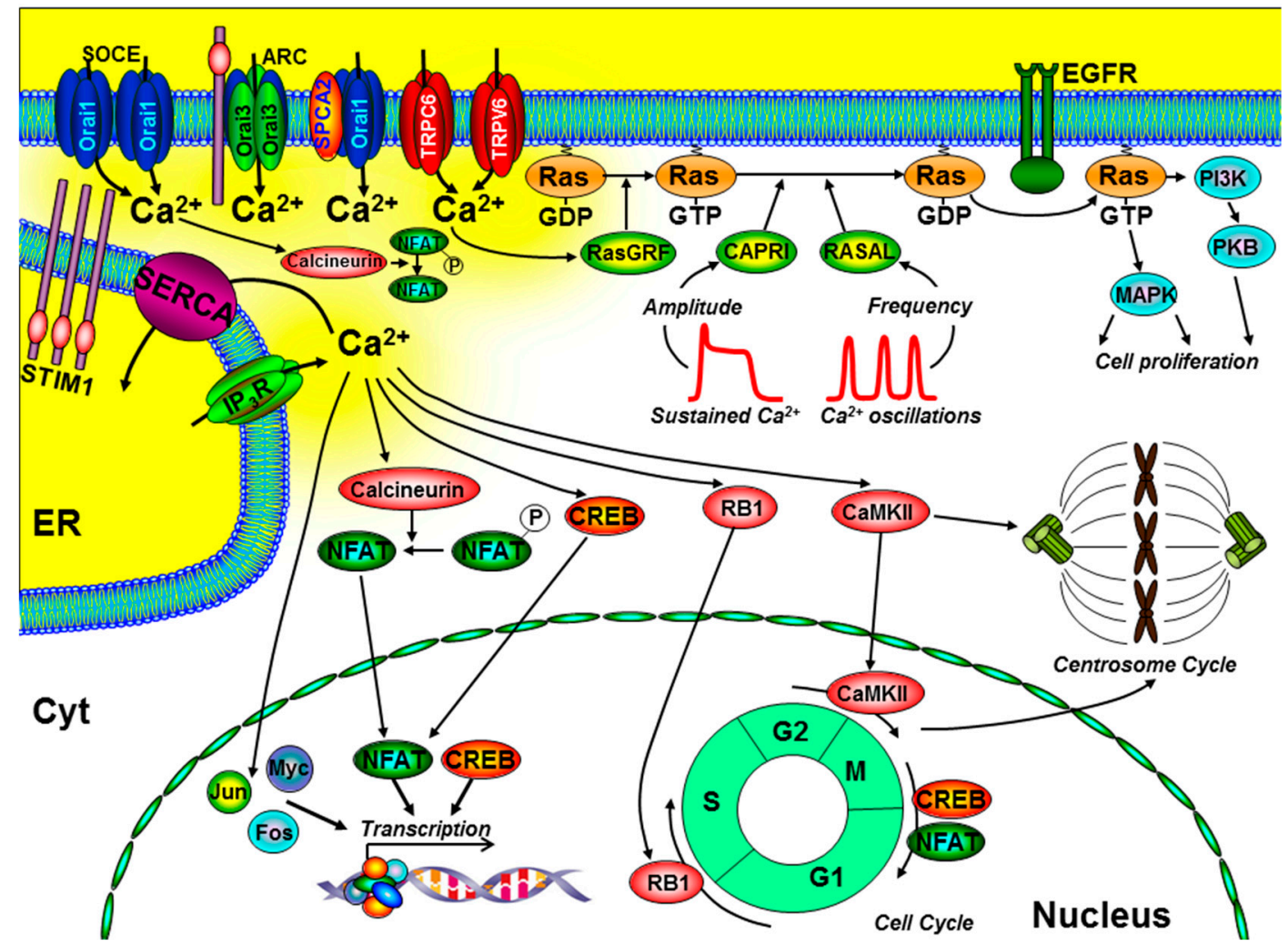

Figure 2. The role of key components of the $\mathrm{Ca}^{2+}$ signalling machinery in the control of cell proliferation and the cell cycle. $\mathrm{Ca}^{2+}$ entry through store-operated $\mathrm{Ca}^{2+}$ channels (SOCE; consisting of endoplasmic reticulum (ER) stromal interacting molecule (STIM) 1 and Orai1), arachidonate-regulated $\mathrm{Ca}^{2+}$ channels (ARC; consisting of plasma membrane STIM1 and Orai1/Orai3 heteropentamers), transient receptor potential channel (TRPC)6, TRPV6, and the non-SOCE (plasma membrane secretory pathway ATPase (SPCA)-regulated Orai1) have all been implicated to regulate cell proliferation. Specific spatiotemporal patterns of $\mathrm{Ca}^{2+}$ signals can differentially regulate gene transcription (via calcineurin/nuclear factor of activated T cells (NFAT), CAMKII/CAMP response element-binding protein (CREB), immediate early genes (Jun, Myc, and Fos)), and the Ras/ERK signalling pathway. Localised $\mathrm{Ca}^{2+}$ entry can specifically activate the Ras guanine exchange factor (Ras-GEF), Ras-GRF, which converts the inactive Ras-guanosine diphoshpate (Ras-GDP) to the activate Ras-guanosine triphoshpate (Ras-GTP). Moreover, the amplitude of $\mathrm{Ca}^{2+}$ signals can specifically activate CAPRI and the frequency of $\mathrm{Ca}^{2+}$ oscillations can specifically activate RASAL, both of which are Ras guanine activating proteins (Ras-GAPs) that inactivate Ras-GTP. $\mathrm{Ca}^{2+}$ also has an important role in the control of the cell cycle and centrosome cycle. Specifically, $\mathrm{Ca}^{2+}$-dependent activation of retinoblastoma-1 (RB1) regulates G1/S phase transition, CaMKII regulates G2/M phase transition, and CREB and NFAT can regulate M/G1 transition. Additional abbreviations include EGFR, epidermal growth factor receptor; PI3K, phosphinositide-3 kinase; PKB, protein kinase-B; MAPK, mitogen-activated kinase; cell cycle phases: G1 and G2, gap; S, synthesis; $\mathrm{M}$, mitosis.

$\mathrm{Ca}^{2+}$ also has an important role at various stages of the cell cycle, especially early G1, G1/S transition, and progression through mitosis [31]. $\mathrm{Ca}^{2+}$-dependent phosphorylation of retinoblastoma-1 (RB1) is one of the key regulatory steps at the G1/S boundary and CaM kinase (CaMK) regulates progression through $\mathrm{G} 1$ and mitosis $[24,25]$. Moreover, the $\mathrm{Ca}^{2+}$-dependent phosphatase, calcineurin, is important during G1 and S phases, owing to the activation of the $\mathrm{Ca}^{2+}$-dependent transcription 
factors, CREB [23] and NFAT [22], which regulate the expression of key cyclin family of proteins (cyclin A, E, and D1) and cyclin-dependent kinases (CDK2, CDK4) [31]. Incidentally, specific $\mathrm{Ca}^{2+}$ entry through Orai1 [32], TRPC6 [33], and TRPV6 [34] has been shown to specifically and efficiently regulate NFAT-mediated gene expression. Furthermore, $\mathrm{Ca}^{2+}$ and CaMKII have been reported to directly regulate centrosome duplication and separation, which, when defective, can lead to aberrant mitotic spindles, aneuploidy, and genetic instability, all hallmarks of cancer [31] (Figure 2).

Another important feature of cancer cells is their limitless replicative capacity [1]. Most normal cells stop dividing after about 50 cell divisions, owing to a shortening of their telomeres during successive cycles of replication. This phenomenon is known as cellular or replicative senescence and can trigger apoptosis if the DNA damage cannot be repaired. One way in which cancer cells can avoid senescence and acquire resistance to apoptosis is to up-regulate telomerase expression to maintain their telomeres. The EF-hand containing $\mathrm{Ca}^{2+}$-binding protein, S100A8, inhibits telomerase activity [35], thereby accelerating cellular senescence. This suggests that remodelling of $\mathrm{Ca}^{2+}$ signalling, and in particular attenuated $\mathrm{Ca}^{2+}$ signaling, likely contributes to cancer cell immortality.

\subsection{Cell Death}

$\mathrm{Ca}^{2+}$ has a critical, yet paradoxical role in regulating cell death [36] and, in particular, both ER $\mathrm{Ca}^{2+}$ and mitochondrial $\mathrm{Ca}^{2+}$ are central to this (Figure 3). Cancer cells adopt strategies to avoid cell death by activating pro-survival pathways and suppressing cell death machinery. The main regulators of cell death include the pro- and anti-apoptotic B-cell lymphoma 2 (Bcl-2) family of proteins; there are currently around 20 different members of this family, though the list continues to grow [37]. The balance between pro-apoptotic (Bax, Bak, and Bad) and anti-apoptotic proteins (Bcl-2/Bcl-xL) determines whether a cell is sensitive or resistant to apoptosis [38] (Figure 3 and Box 2). The phosphorylation status of Bad is a critical checkpoint for apoptosis (Figure 3 and Box 2).

Box 2. Cell Death.

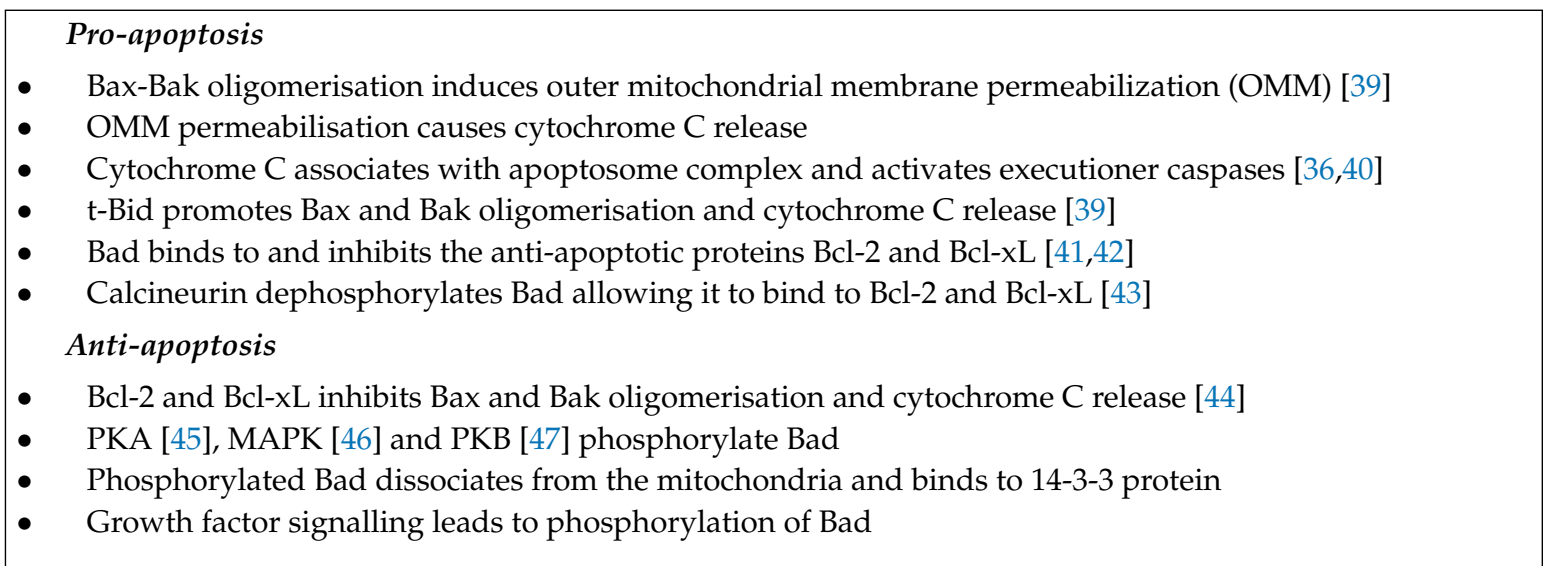

When phosphorylated by protein kinase-A (PKA), protein kinase-B (PKB), or Ras-mitogen activated kinase (MAPK), Bad dissociates from the mitochondria to the cytosol, where it binds to 14-3-3 protein, which prevents it from engaging and inhibiting the anti-apoptotic Bcl-2/Bcl-xL; this ultimately inhibits apoptosis [42] (Figure 3 and Box 2). On the other hand, the $\mathrm{Ca}^{2+}$-dependent activation of calcineurin leads to the dephosphorylation of Bad, allowing it to bind to and inhibit Bcl-2/Bcl-xL, thereby promoting apoptosis [43]. It is also interesting to note that 14-3-3 proteins have been reported to inhibit the PMCA [48], thereby accentuating the $\mathrm{Ca}^{2+} /$ calcineurin-mediated dephosphorylation of Bad and further potentiating this $\mathrm{Ca}^{2+}$-mediated apoptosis. Therefore, a remodelling of the $\mathrm{Ca}^{2+}$ signalling machinery that leads to "dampening" of $\mathrm{Ca}^{2+}$ signals can result in apoptosis resistance. 


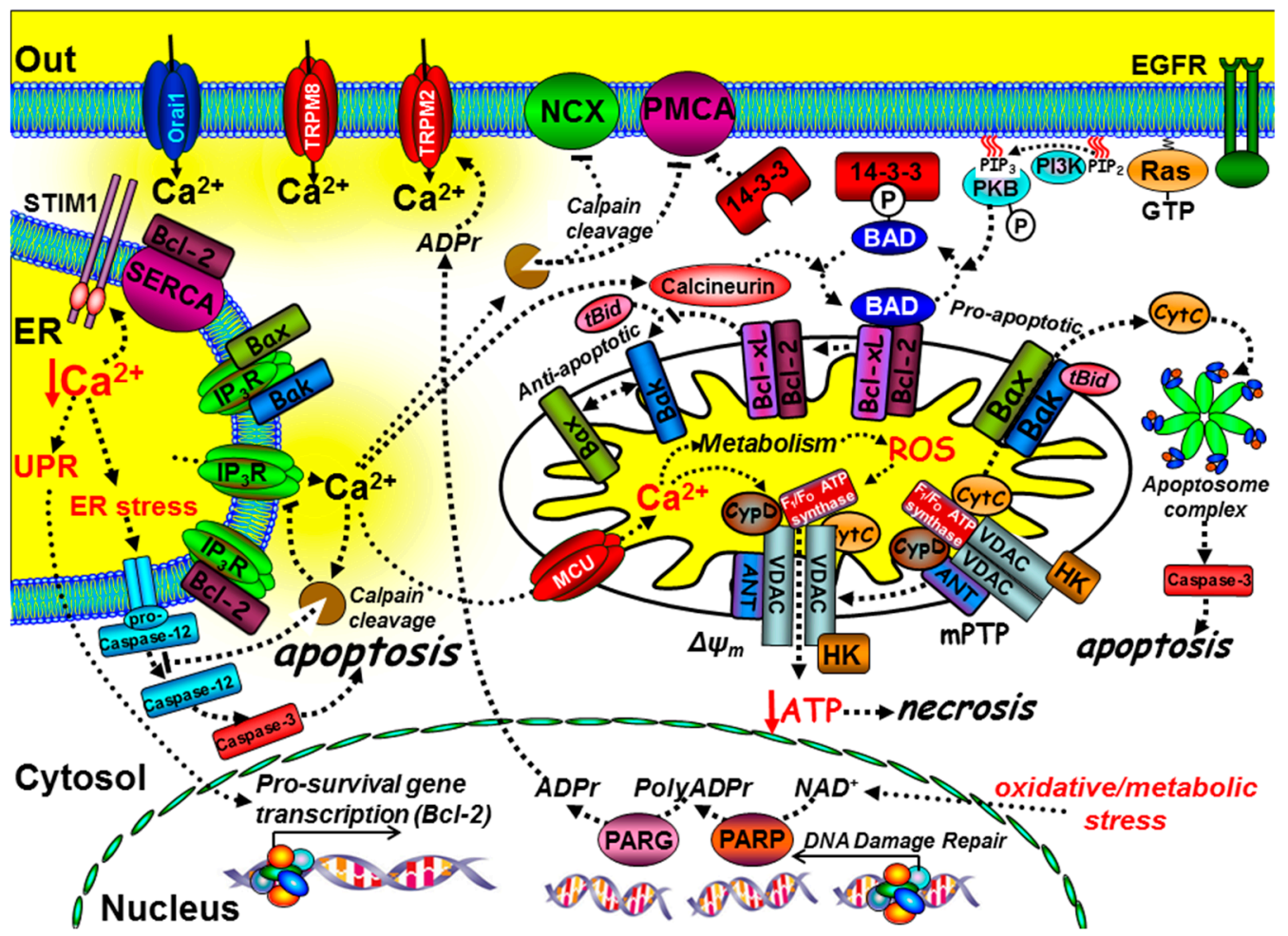

Figure 3. The role of key components of the $\mathrm{Ca}^{2+}$ signalling machinery in cell death and immortality. $\mathrm{Ca}^{2+}$ mediates intrinsic cell death at both the mitochondria and ER. At the mitochondria, tBid binds to and promotes Bax and Bak oligomerisation into pores that release cytochrome C, which binds to the apoptosome complex and activates the executioner caspases, such as caspase-3, leading to the "point-of-no-return" apoptotic cascade. The anti-apoptotic proteins, Bcl-2 and Bcl-xL, can prevent the $\mathrm{t}$-Bid/Bax/Bak interaction, thereby preventing apoptosis. The pro-apoptotic protein Bad binds to $\mathrm{Bcl}-2 / \mathrm{Bcl}-\mathrm{xL}$, thereby preventing their interaction with the $\mathrm{t}-\mathrm{Bid} / \mathrm{Bax} / \mathrm{Bak}$ complex, thus promoting apoptosis. Phosphorylation of Bad, via growth factor receptor-mediated activation of protein kinase-B (PKB), causes Bad to dissociate from the mitochondria and bind to 14-3-3 protein. Sustained $\mathrm{Ca}^{2+}$ overload can activate calcineurin, which dephosphorylates Bad, allowing it to sequester the anti-apoptotic proteins, Bcl-2/Bcl-xL. $\mathrm{Ca}^{2+}$ uptake into the mitochondria, via the mitochondrial $\mathrm{Ca}^{2+}$ uniporter (MCU), can lead to the production of reactive oxygen species (ROS). $\mathrm{Ca}^{2+}$ and ROS can activate the permeability transition pore (mPTP), loss of the mitochondrial membrane potential $(\triangle \Psi \mathrm{m}), \mathrm{ATP}$ depletion and necrosis. $\mathrm{Ca}^{2+}$ overload can also activate calpain and cleavage of the PMCA, $\mathrm{Na}^{+} / \mathrm{Ca}^{2+}$-exchange (NCX), and inositol 1,4,5-trisphosphate receptors (IP3Rs). Bax, Bak, and Bcl-xL can also bind to and inhibit $\mathrm{IP}_{3}$ Rs. Bcl-2 can bind to and inhibit SERCA, reducing ER Ca ${ }^{2+}$.

In addition, $\mathrm{Ca}^{2+}$ has a more prominent role during cell stress-induced cell death [36] (Figure 3). Mitochondria take up $\mathrm{Ca}^{2+}$ via a low affinity mitochondrial $\mathrm{Ca}^{2+}$ uniporter (MCU) [49,50]. MCU is important for the activation of a number of key metabolic enzymes [51], a process referred to as stimulus-metabolism coupling. Owing to the low affinity of the MCU, many mitochondria are strategically positioned in close proximity to either $\mathrm{Ca}^{2+}$ entry channels or $\mathrm{Ca}^{2+}$ release channels in order to maximise mitochondrial $\mathrm{Ca}^{2+}$ uptake [52]. Some studies have shown that this is a dynamic process to meet the energy demands of the cell $[53,54]$. However, sustained and excessive cytosolic $\mathrm{Ca}^{2+}$ overload can lead to excessive mitochondrial $\mathrm{Ca}^{2+}$ uptake and an elevated mitochondrial matrix $\mathrm{Ca}^{2+}$ concentration, which in turn can lead to the production of reactive oxygen species (ROS) [55]. This is a common phenomenon in many diseases in which there is $\mathrm{Ca}^{2+}$-mediated and/or oxidative stress-dependent cell death or cellular injury. However, down-regulation of MCU expression, mediated by the over-expression of the cancer-related MCU-targeted microRNA, miR-25, has been reported to contribute to apoptosis resistance in colon cancer [56]. In addition, ROS have multiple 
and complex effects on both pro-survival pathways and the $\mathrm{Ca}^{2+}$ signalling machinery. For example, ROS can induce the cleavage and thus inactivation of PKB [57], yet it can also oxidise and inactivate phosphatidylinositol-3,4,5-trisphosphate ( $\left.\mathrm{PIP}_{3}\right)$ 3-phosphatase (PTEN), which paradoxically increases PKB activity [58]. ROS can amplify receptor tyrosine kinase (RTK) signalling, via activation of PLC $\gamma$ and $\mathrm{IP}_{3}$ production [59]. Furthermore, $\mathrm{ROS}$ can directly sensitize $\mathrm{Ca}^{2+}$ release channels [60] and activate TRPM2 channels [61]. Both ROS and $\mathrm{Ca}^{2+}$ can activate the mitochondrial permeability transition pore (mPTP) [55], which consists of the voltage-dependent anion channel (VDAC), adenine nucleotide translocase (ANT), and cyclophilin-D [62] (Figure 3). This molecular machine is responsible for coupling mitochondrial volume and ion homeostasis with metabolism and cellular stress (see Box 3). The MPTP sits at the inner mitochondrial membrane (IMM)-outer mitochondrial membrane (OMM) interface; excessive activation thus leads to mitochondrial swelling owing to impaired mitochondrial ion homeostasis (Box 3) and OMM rupture, which can also cause the release of cytochrome C (Figure 3) [36].

Box 3. $\mathrm{Ca}^{2+}$ and Ion Homeostasis.

$\mathrm{Ca}^{2+}$ is inextricably linked to cytosolic ion homeostasis, cell volume regulation and intracellular $\mathrm{pH}$ regulation as well as mitochondrial ion homeostasis and volume regulation. These have all been separately implicated in the regulation of numerous cellular functions including the key cancer phenotypes of cell migration, invasion, cell proliferation and cell death. There are numerous $\mathrm{Ca}^{2+}$-dependent ion channels, such as $\mathrm{Ca}^{2+}$-dependent $\mathrm{K}+$ channels (e.g., BKCa, IKCa, SKCa), $\mathrm{Ca}^{2+}$-dependent Cl- channels (e.g., TMEM16A) that are expressed on the plasma membrane and also the mitochondrial membrane. $\mathrm{Ca}^{2+}$ flux through $\mathrm{Ca}^{2+}$ channels and the activation $\mathrm{Ca}^{2+}$-dependent ion channels on either the plasma membrane or mitochondrial membrane can affect the membrane potential and thus the driving force for most ion channels and transporters in that membrane.

For many years, the mPTP was thought to be important for $\mathrm{Ca}^{2+}$-mediated apoptosis $[63,64]$; however, knockout studies of VDAC [65] and cyclophilin-D [66,67] had no effect on apoptosis, but attenuated necrotic cell death. This suggests that the MPTP may be more important during necrotic cell death than for apoptosis. Nevertheless, it is clear that the MPTP can functionally interact with $\mathrm{Bcl}-2 / \mathrm{Bcl}-\mathrm{xL}$ and Bax/Bak $[63,64,68,69]$, suggesting that necrosis and apoptosis may share some of the same molecular machinery. The defining feature of necrosis is that this is usually accompanied by the collapse of the mitochondrial membrane potential, owing to excessive activation of the MPTP and the consequent inhibition of mitochondrial ATP synthesis. This can have a knock-on effect on $\mathrm{Ca}^{2+}$ homeostasis, specifically owing to the inhibition of the ATP-dependent $\mathrm{Ca}^{2+}$ pumps (PMCA and SERCA), but also inhibition of the $\mathrm{Na}^{+} / \mathrm{K}^{+}$-ATPase, which is important for maintaining the plasma membrane potential, and thus the driving force for $\mathrm{Ca}^{2+}$ entry (Box 3 and Figure 4). Clearly, enhanced $\mathrm{Ca}^{2+}$ signalling and $\mathrm{Ca}^{2+}$ overload promote $\mathrm{Ca}^{2+}$-mediated cell death (necrosis and apoptosis). However, there is extensive evidence that remodelling of the $\mathrm{Ca}^{2+}$ signalling machinery that leads to an overall "dampening" of $\mathrm{Ca}^{2+}$ signals can result in apoptosis resistance, an important hallmark of cancer (Figure 3).

In addition to mitochondrial $\mathrm{Ca}^{2+}$ content, cell death pathways are also influenced by $\mathrm{ER} \mathrm{Ca}^{2+}$ content. $\mathrm{ER} \mathrm{Ca}^{2+}$ concentration is critical for the correct synthesis, folding, and processing of newly synthesised proteins. Perturbation of ER $\mathrm{Ca}^{2+}$ can lead to either accumulated protein or incorrectly folded proteins, resulting in ER stress or the unfolded protein response (UPR) [70]. This leads to the activation of numerous ER chaperone proteins and transcriptional control of pro-survival genes (e.g., Bcl-2/Bcl-XL) and inhibition of the protein translation machinery, both of which are generally regarded as cytoprotective. However, prolonged and excessive ER stress or cytosolic $\mathrm{Ca}^{2+}$ overload can lead to the activation of m-calpain and the cleavage of pro-caspase-12, which normally resides on the ER membrane [71]. The cleavage product (caspase-12) can then activate downstream executioner caspases that engage a "point of no return" apoptosis cascade [71]. $\mathrm{Ca}^{2+}$ can also amplify cell death by activating cytosolic calpains [72], which can directly activate caspases [73] and inactivate the anti-apoptotic Bcl-2 [74], the $\mathrm{Na}^{+} / \mathrm{Ca}^{2+}$-exchange (NCX), and the PMCA [75-79] (Figure 3). 


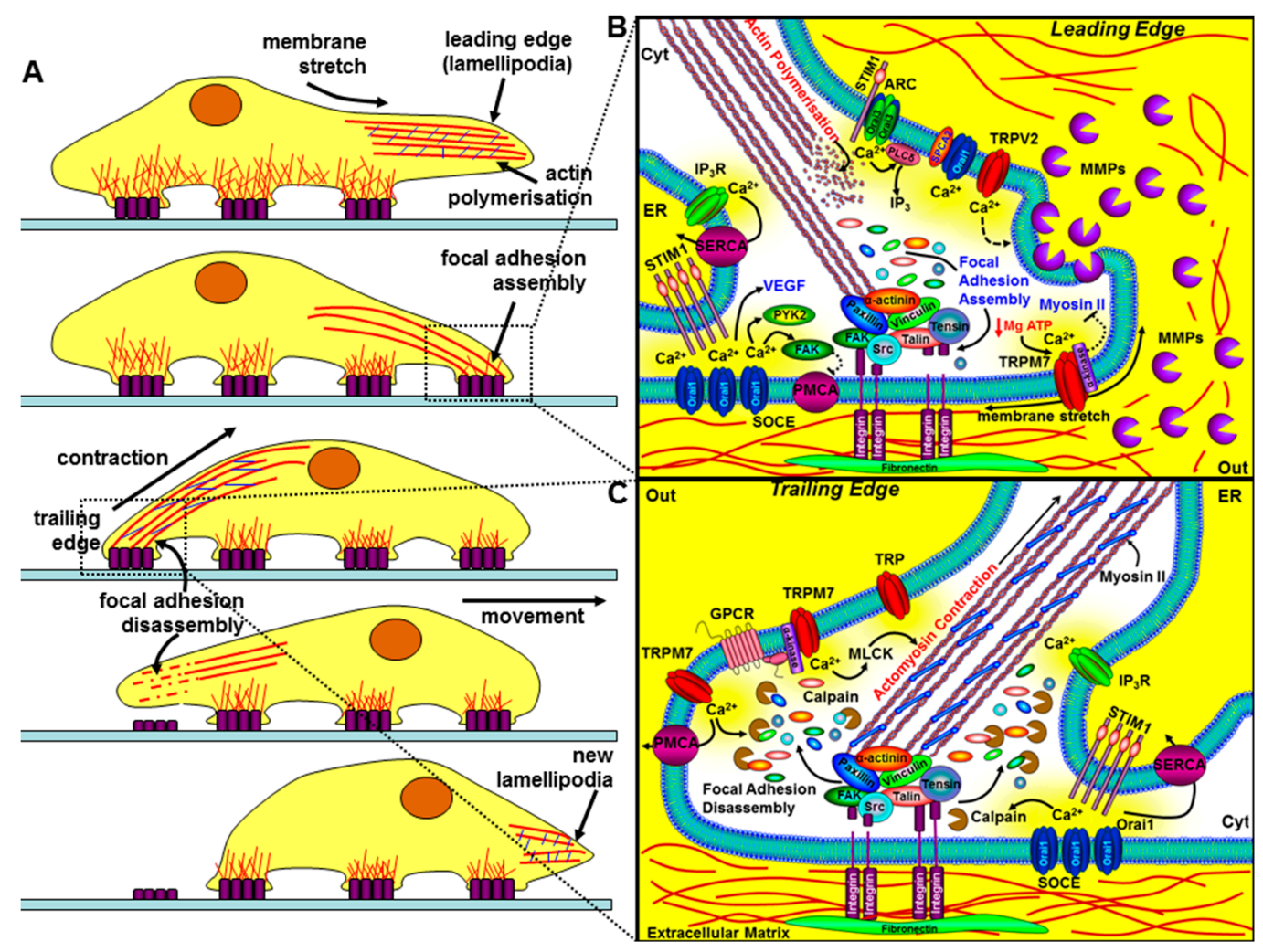

Figure 4. The role of key components of the $\mathrm{Ca}^{2+}$ signalling machinery in cell migration and invasion. The left panel (A) depicts the sequential steps of a migrating cell. The bottom part of the cell makes contact with the extracellular matrix (ECM) via integrins (purple rectangles), which couple the ECM to the actin cytoskeleton. The leading edge involves specialised membrane protrusions (lamellipodia/invadapodia) containing matrix metalloproteinases (MMPs), actin polymerisation, the assembly of focal adhesions, and the formation of new integrin-mediated contact sites. The trailing edge requires focal adhesion disassembly, actomyosin contraction, and the loss of rear-end contact sites. The right panels (B and $\mathbf{C}$ ) show a magnified view of how key components of the $\mathrm{Ca}^{2+}$ signalling machinery regulate the leading edge $(\mathbf{B})$ and the trailing edge of a migrating cell (C). At the leading edge, specific localised $\mathrm{Ca}^{2+}$ entry, amplified by $\mathrm{Ca}^{2+}$ release through $\mathrm{IP}_{3} \mathrm{Rs}$, can lead to focal adhesion assembly via the $\mathrm{Ca}^{2+}$-dependent activation of calmodulin-dependent kinase (CaMKII), proline-rich tyrosine kinase (PYK2), and focal adhesion kinase (FAK). $\mathrm{Ca}^{2+}$ entry through store-operated $\mathrm{Ca}^{2+}$ channels (SOCE; consisting of ER STIM1 and Orai1), TRPM7, TRPV2, arachidonate-regulated $\mathrm{Ca}^{2+}$ channels (ARC; consisting of plasma membrane STIM1 and Orai1/Orai3 heteropentamers), and the non-SOCE (plasma membrane SPCA-regulated Orai1) have all been implicated in the regulation of cell migration and invasion. Membrane stretch can activate $\mathrm{Ca}^{2+}$ entry through TRPM7 and the $\alpha$-kinase domain of TRPM7 can also phosphorylate myosin-IIA heavy chain and inhibit actomyosin contraction and lead to cell spreading. $\mathrm{Ca}^{2+}$ entry through TRPV2 has also been shown to regulate the release of MMPs and the focal degradation of the ECM. At the trailing edge, $\mathrm{Ca}^{2+}$ entry through SOCE and TRPM7 channels leads to the coordinated $\mathrm{Ca}^{2+}$-dependent activation of $\mathrm{m}$-calpain, leading to focal adhesion disassembly, and myosin light chain kinase activation, leading to actomyosin contraction.

Paradoxically, some of the pro-apoptotic and anti-apoptotic proteins have been reported to directly regulate key $\mathrm{Ca}^{2+}$ transport proteins including $\mathrm{IP}_{3} \mathrm{Rs}$ [80,81], SERCA [82], PMCA [83], and MCU [84], resulting in a complex reciprocal regulation between $\mathrm{Ca}^{2+}$ signalling and cell death. Specifically, cytochrome $\mathrm{C}$, once released from mitochondria, can bind to and potentiate $\mathrm{Ca}^{2+}$ release from $\mathrm{IP}_{3} \mathrm{Rs}^{2}[85]$, suggesting a feed-forward potentiation of apoptosis. Bax and Bak can regulate $\mathrm{IP}_{3} \mathrm{Rs}$ [86,87]. Bcl-2 is reported to reduce ER $\mathrm{Ca}^{2+}[80,81]$ and directly inhibit $\mathrm{IP}_{3} \mathrm{Rs}$ [88] and SERCA [82], which leads to reduced $\mathrm{Ca}^{2+}$ release and mitochondrial $\mathrm{Ca}^{2+}$ uptake. Although such remodelling of the $\mathrm{Ca}^{2+}$ 
signalling machinery may have evolved to attenuate $\mathrm{Ca}^{2+}$-mediated cell death, paradoxically, this may also result in apoptosis resistance (Figure 3).

Under metabolic or oxidative stress, free ADP-ribose is generated by the DNA repair machinery (poly (ADP-ribose polymerase (PARP1)/poly(ADP)-ribose glycohydrolase (PARG)) [89], resulting in the activation of $\mathrm{Ca}^{2+}$ entry through TRPM2, which likely contributes to the further activation of $\mathrm{Ca}^{2+}$-mediated cell death pathways [17] (Figure 3).

\subsection{Migration and Invasion}

Chemo-attractant-induced cellular migration involves the coordinated and dynamic regulation of structural and signalling linkages between the extracellular matrix and cytoskeleton, involving integrins, focal adhesion complexes [90], and the contractile machinery [91]. Accumulating evidence points to an increasingly important role of spatiotemporally distinct $\mathrm{Ca}^{2+}$ signals in directional sensing, redistribution of the actin cytoskeleton, traction force generation, and focal adhesion turnover [92]. Migrating cells exhibit a rear-to-front $\mathrm{Ca}^{2+}$ gradient responsible for the rear end retraction [93]. This is owing to the $\mathrm{Ca}^{2+}$-dependent activation of myosin light chain kinase (MLCK) and subsequent actomyosin contraction [94], and focal adhesion disassembly by $\mathrm{Ca}^{2+}$-dependent calpain cleavage of focal adhesion kinase (FAK), integrins, talin, and vinculin [95] (Figure 4). However, the leading edge of the migrating cells exhibit spatially confined $\mathrm{Ca}^{2+}$ oscillations, or " $\mathrm{Ca}^{2+}$ flickers", that specifically activate focal adhesion assembly, and thus the growth and steering of the migrating cell $[96,97]$. This is owing to the specific $\mathrm{Ca}^{2+}$-dependent activation of CaMKII [98] and proline-rich tyrosine kinase-2 (PYK-2) [99], which leads to the tyrosine and serine phosphorylation of focal adhesion kinase (FAK), respectively. It is also important to note that activation of FAK has been reported to inhibit PMCA4b in platelets [100], which, if extrapolated, might accentuate localised $\mathrm{Ca}^{2+}$ signals at the leading edge of the migrating cell (Figure 4).

In the case of cancer cells, the leading edge is often referred to as the "invadopodia"-membrane protrusions that contain proteolytically active matrix metalloproteinases (MMPs) to focally degrade the extracellular matrix (ECM) [101] (Figure 4). Furthermore, the EF hand $\mathrm{Ca}^{2+}$-binding protein, S100A4, has been shown to translocate from the nucleus to the plasma membrane in response to an increase in cytosolic $\mathrm{Ca}^{2+}$ in migrating cancer cells [102]. S100A4 has been implicated in metastasis of cancer cells by interacting with non-muscle myosin IIA, IIB, and tropomyosin, thereby indirectly regulating migration [103]. Moreover, S100A4 has been shown to increase the expression of MMP9, leading to the proteolytic cleavage of the ECM and an increased invasive phenotype [104].

There are numerous mechano-sensitive $\mathrm{Ca}^{2+}$-permeable channels that sense membrane stretch at the leading edge of migrating cancer cells (Box 4).

Box 4. Mechanosensitive $\mathrm{Ca}^{2+}$ Channels and Cancer.

- $\quad$ Piezo1 and 2 are bona fide mechanosensitive non-selective $\mathrm{Ca}^{2+}$ permeable cation channels stimulated by all types of mechanical stimuli to the plasma membrane [105-108]

- Piezo channels are overexpressed in gastric, breast, prostate and glioma where they regulate cell proliferation, migration/invasion and angiogenesis but are oncosuppressors in lung and osteosarcoma [106]

- $\quad$ TRPM7 is a bi-functional stretch-activated $\mathrm{Ca}^{2+}$ and $\mathrm{Mg}^{2+}$ permeable channel $[109,110]$

- $\quad$ TRPV2 is a heat/mechano-sensitive $\mathrm{Ca}^{2+} / \mathrm{Mg}^{2+}$ permeable channel expressed in human leukemia cells [111]

- Panexins (Panx1) are mechanosensitive channels permeable to ATP which activate P2X7 purinergic ATP-gated $\mathrm{Ca}^{2+}$ permeable channels both of which are important in cancer $[112,113]$

- $\quad$ Polycyctins (TRPP1, TRPP2) are multi-functional mechanosensitive $\mathrm{Ca}^{2+}$ permeable channels that are over-expressed and facilitate an aggressive phenotype in colorectal cancer [114]

- $\quad$ TRPC1, TRPC2, TRPV1, TRPM3, TRPM4, TRPA1 also exhibit mechanosensitivity $[113,115]$

Arguably one of the most studied and potentially important of these stretch-activated $\mathrm{Ca}^{2+}$ channels involved in migration in non-cancer cells is TRPM7. This bi-functional $\mathrm{Ca}^{2+}$ and $\mathrm{Mg}^{2+}$ permeable 
channel, with a functionally separate regulatory $\alpha$-kinase domain, can be activated by mechanical force, phospholipase-C (PLC)-coupled agonists, and Mg-ATP depletion [110] (Figure 4 and Box 5).

Box 5. TRPM7 and Cellular Migration.

- $\quad$ TRPM7 is a bi-functional stretch-activated $\mathrm{Ca}^{2+}$ and $\mathrm{Mg}^{2+}$ permeable channel $[109,110]$

- $\quad$ TRPM7 contains a functionally separate $\alpha$-kinase domain $[109,110]$

- $\quad$ TRPM7 is activated by mechanical force, PLC-coupled agonists and Mg-ATP depletion $[109,110]$

- $\quad$ TRPM7 facilitates spatially confined $\mathrm{Ca}^{2+}$ signals at the leading edge of migrating cells $[96,116]$

- $\quad \mathrm{Ca}^{2+}$ entry through TRPM7 activates calpain cleavage of focal adhesions [117]

- $\quad$ The TRPM7 $\alpha$-kinase domain inhibits actomyosin contraction and facilitates cell spreading [118]

\subsection{Angiogenesis}

Cancer cells secrete a variety of growth factors, most notably vascular endothelial growth factor (VEGF), which have potent mitogenic and angiogenic effects on adjacent endothelial cells, causing cell proliferation, tube formation, and thus growth of new blood vessels [119]. Ironically, the mitogenic and angiogenic effects of VEGF in endothelial cells are mediated by $\mathrm{Ca}^{2+}$ signalling [120]. Most notably, Orai1 and STIM1 have been shown to mediate VEGF-induced endothelial cell migration, tube formation, and angiogenesis [120]. In addition, various TRP channels have been implicated in agonist and stretch-induced $\mathrm{Ca}^{2+}$ entry-mediated angiogenesis and microvascular permeability [119].

\section{Opportunities for Targeting the $\mathrm{Ca}^{2+}$ Signalling Machinery in Cancer}

There is extensive evidence that the expression of numerous $\mathrm{Ca}^{2+}$ channels and transporters is altered in many different types of cancer; in most cases, this is an over-expression, but in some cases, down-regulation, with both potentially leading to tumorigenesis and cancer progression (Table 1).

Table 1. Altered expression of components of the $\mathrm{Ca}^{2+}$ signalling machinery during cancer. An increase or decrease in expression is indicated by the appropriate arrow. Each $\mathrm{Ca}^{2+}$ transporter is sub-categorised into store-operated $\mathrm{Ca}^{2+}$ channel (SOCE)/non-SOCE, transient receptor potential (TRP) channels, $\mathrm{Ca}^{2+}$ ATPases, and $\mathrm{Ca}^{2+}$ release channels. STIM, stromal interacting molecule; TRPV, TRP vanilloid; TRPM, TRP melastatin.

\begin{tabular}{cccc}
\hline Ca $^{2+}$ Transporter & Expression & Cancer Type & Reference \\
\hline SOCE/non-SOCE & & & \\
Orai1 & $\uparrow$ & Breast & {$[121-123]$} \\
& $\uparrow$ & Kidney & {$[124,125]$} \\
& $\uparrow$ & Prostate & {$[126]$} \\
Orai3 & $\downarrow$ & Prostate & {$[127]$} \\
& $\uparrow$ & Oesophageal & {$[128]$} \\
& $\uparrow$ & Breast & {$[123,129-131]$} \\
STIM1 & $\downarrow$ & Prostate & {$[126]$} \\
& $\uparrow$ & Prostate & {$[132]$} \\
STIM2 & $\uparrow$ & Lung & {$[133]$} \\
TRP channels & $\uparrow$ & Cervical & {$[134]$} \\
TRPC1 & $\downarrow$ & Breast & {$[122,135]$} \\
TRPC2 & $\uparrow$ & Breast & {$[122]$} \\
& $\uparrow$ & & \\
& $\uparrow$ & Breast & {$[136]$} \\
& $\uparrow$ & Breast & {$[137]$} \\
\hline
\end{tabular}


Table 1. Cont.

\begin{tabular}{|c|c|c|c|}
\hline $\mathrm{Ca}^{2+}$ Transporter & Expression & Cancer Type & Reference \\
\hline \multirow[t]{4}{*}{ TRPC6 } & $\uparrow$ & Breast & {$[136,137]$} \\
\hline & $\uparrow$ & Glioma & [139] \\
\hline & $\uparrow$ & Liver & [140] \\
\hline & $\uparrow$ & Oesophageal & [141] \\
\hline \multirow[t]{3}{*}{ TRPM7 } & $\uparrow$ & Pancreatic & [142] \\
\hline & $\uparrow$ & Breast & [136] \\
\hline & $\uparrow$ & Nasopharyngeal & [143] \\
\hline \multirow[t]{7}{*}{ TRPM8 } & $\uparrow$ & Pancreatic & [144] \\
\hline & $\uparrow$ & Prostate & {$[145,146]$} \\
\hline & $\uparrow$ & Breast & {$[136,146]$} \\
\hline & $\uparrow$ & Melanoma & [146] \\
\hline & $\uparrow$ & Colorectal & [146] \\
\hline & $\uparrow$ & Lung & [146] \\
\hline & $\uparrow$ & Glioblastoma & {$[147,148]$} \\
\hline \multirow[t]{3}{*}{ TRPV1 } & $\uparrow$ & Liver & [149] \\
\hline & $\downarrow$ & Bladder & [150] \\
\hline & $\uparrow$ & Prostate & [151] \\
\hline TRPV2 & $\uparrow$ & Prostate & [152,153] \\
\hline \multirow[t]{5}{*}{ TRPV6 } & $\uparrow$ & Breast & {$[136,154-156]$} \\
\hline & $\uparrow$ & Prostate & {$[155,156]$} \\
\hline & $\uparrow$ & Thyroid & [156] \\
\hline & $\uparrow$ & Colon & [156] \\
\hline & $\uparrow$ & Ovarian & [156] \\
\hline \multicolumn{4}{|l|}{$\mathrm{Ca}^{2+}$ ATPase } \\
\hline PMCA2 & $\uparrow$ & Breast & {$[157,158]$} \\
\hline PMCA4 & $\downarrow$ & Colon & [159] \\
\hline SERCA2 & $\downarrow$ & Oral & [160] \\
\hline \multirow[t]{2}{*}{ SERCA3 } & $\downarrow$ & Colon & [161] \\
\hline & $\downarrow$ & Breast & [162] \\
\hline \multicolumn{4}{|l|}{$\mathrm{Ca}^{2+}$ release channels } \\
\hline $\mathrm{IP}_{3} \mathrm{R}-1$ & $\downarrow$ & Glioblastoma & [163] \\
\hline $\mathrm{IP}_{3} \mathrm{R}-2$ & $\uparrow$ & & \\
\hline \multirow[t]{2}{*}{$\mathrm{IP}_{3} \mathrm{R}-3$} & $\uparrow$ & Glioblastoma & [163] \\
\hline & $\uparrow$ & Colon & [164] \\
\hline
\end{tabular}

However, despite the extensive remodelling of the $\mathrm{Ca}^{2+}$ signalling machinery that occurs during cancer, it is very difficult to determine whether a change in expression is the cause or consequence of cancer progression. In addition, up-regulation of $\mathrm{Ca}^{2+}$ channels and transporters does not guarantee that these would necessarily represent ideal therapeutic targets, especially when one considers the ubiquitous nature of $\mathrm{Ca}^{2+}$ signalling. Therefore, any drug designed to target such a $\mathrm{Ca}^{2+}$ channel/transporter would be expected to have adverse effects, regardless of the specificity of such a drug. Therefore, an ideal therapeutic target would be one that is either uniquely expressed in cancer or whose expression leads to a totally novel function in cancer cells.

\subsection{TRP Channels}

Several TRP channels are reported to be overexpressed in cancer (Table 1). To date, the most well studied TRP channel in this context is TRPM7, a $\mathrm{Ca}^{2+}$-permeable nonselective cation channel with a kinase domain. TRPM7 has a role in mechanosensory signalling and the regulation of cellular contractility, adhesion, and migration. TRPM7 expression is elevated in ovarian [165], pancreatic [166,167], bladder [168], and breast [169] cancers, with high expression correlated with tumour growth, metastasis, and poor prognosis (see Box 5). 
Moreover, TRPM7 has been linked to epithelial-mesenchymal transition (EMT, a key process underlying cancer cell motility and metastasis) in numerous cancers. In breast cancer cells, TRPM7 influences EMT by regulating the transcription factor SOX4 via changes in cell tension [170]. TRPM7 has been linked with EMT in ovarian [171] and bladder [172] cancers, the former by calcium-dependent regulation of the PI3K/AKT pathway, and appears to regulate transforming growth factor- $\beta$ (TGF $\beta$ )-induced cell migration and EMT in prostate cancer cells [173]. In nasopharyngeal carcinoma cells, bradykinin-induced stimulation and over-expression of TRPM7 increased migration, whereas inhibition (with $\mathrm{La}^{3+}$ or 2-APB) and RNAi silencing of TRPM7 inhibit migration [143]. In human lung adenocarcinoma A549 cells, enhanced surface expression of TRPM7 contributes to both basal and EGF-stimulated migration [174]. Nuclear accumulation of myocardin related transcription factor-A in hepatocellular carcinoma cells (a known regulator of oncogenic transformation) was inhibited by TRPM7 channel blockade with NS8593 or knockdown by siRNA [175]. Interestingly, blockade of the TRPM7 kinase domain inhibited its regulation of focal adhesions and the cytoskeleton and resulted in inhibited cell migration in MDA-MB-231 cells [176], indicating a role for the TRPM7 kinase domain in metastasis. Moreover, hypoxia-induced ATP depletion stimulates TRPM7 activity, which facilitates cancer cell migration via activation of m-calpain and focal adhesion turnover [177].

In addition to being an attractive therapeutic target, TRPM7 is also a good prognostic marker for breast cancer. Tumour TRPM7 mRNA expression correlates with the incidence of reoccurrence and metastasis in breast cancer patients [178]. Xenograft models of human breast cancer revealed that increased TRPM7 expression led to increased invasiveness and metastasis [178]. Furthermore, TRPM7 has a 13-fold higher expression in pancreatic ductal adenocarcinoma (PDAC) compared with non-cancer tissue, with TRPM7 expression correlated with tumour progression and a poor survival rate [142]. Interestingly, the observation in this study that siRNA silencing of TRPM7 inhibits BxPC-3 cell migration without affecting proliferation suggests that TRPM7 specifically regulates the invasive phenotype of PDAC [142]. Furthermore, TRPM7 has recently been identified as a regulator of SOCE, despite not being a store-operated channel itself [179], with implications for crosstalk between TRPM7 channels and SOCE in cancer.

Collectively, these studies suggest that TRPM7 may represent a good therapeutic target to prevent a metastatic cancer cell phenotype. However, while the TRPM7 activator naltriben appears to enhance the invasive behaviour of glioblastoma multiforme cell line U87 [180] and TRPM7-selective inhibitors (Waixenicin A) that have been described [181,182], it remains to be determined whether pharmacological blockade of TRPM7 has any cancer-specific therapeutic potential in the clinic.

Beyond TRPM7, other melastatin-related TRP family receptors with putative roles in cancer progression are TRPM1 and TRPM8. TRPM1 expression appears to be inversely correlated to an aggressive metastatic melanoma phenotype [183] and has been described as a tumour suppressor. Over-expression of TRPM8 in PC-3 prostate cancer cells induced cell cycle arrest, facilitated starvation-induced apoptosis, and reduced migration, owing to the inactivation of focal adhesion kinase (FAK) [184]. More recent studies have shown that androgen receptors regulate prostate cancer cell migration via inhibition of TRPM8 and lowering of $\left[\mathrm{Ca}^{2+}\right]_{i}[185]$. This raises the possibility of using a TRPM8 activator to inhibit metastatic cells. Indeed, the classical TRPM8 agonist menthol has been shown to inhibit cell proliferation, induce cell cycle arrest, and inhibit migration of the androgen-independent DU145 prostate cancer cell line [186].

Transient receptor potential vanilloid 6 (TRPV6) is another TRP channel that has been suggested as a target for cancer [187]. TRPV6 is overexpressed in numerous solid tumours, including breast, colon, ovarian, prostate, and thyroid carcinomas [156], and is associated with poor prognosis [188]. The aberrant cell surface expression of TRPV6 in prostate cancer is increased in prostate cancer cells via SOCE-dependent activation of the Annexin I/S100A11 complex [189]. Moreover, this TRPV6 overexpression confers apoptosis resistance and aggressive behaviour in vivo [189]. Similarly, TRPV6 silencing in breast cancer cells with increased endogenous TRPV6 led to lower basal calcium influx and reduced proliferation [190]. Elevated TRPV6 is associated with poor prognosis in pancreatic 
cancer; moreover, knockdown of TRPV6 decreased Bcl-2 and increased BAX in Capan-2 cells, inhibiting proliferation and migration, while promoting apoptosis [191]. Interestingly, in human small cell lung carcinoma cells, the classical TRPV1 agonist capsaicin induces apoptosis via TRPV6, independent of TRPV1, in a $\mathrm{Ca}^{2+}$ - and calpain-dependent manner [192]. These advances have led to preclinical and clinical studies assessing TRPV6 as a therapeutic target; the selective TRPV6 inhibitor SOR-C13 has shown promise in both in vivo models of cancer [193] and early clinical trials in patients with advanced tumours of epithelial origin [194].

Another TRPV channel involved in regulation of breast cancer cell angiogenesis and migration is TRPV4. Evidence from endothelial cells (ECs) derived from human breast carcinomas suggests that arachidonate-induced intracellular $\mathrm{Ca}^{2+}$ signals mediated by TRPV4 contribute to tumour angiogenesis [195]. Knockdown of TRPV4 decreases breast cancer cell invasiveness in vitro and lung metastasis in vivo [196], and further investigation revealed that TRPV4 promotes breast cancer metastasis via $\mathrm{Ca}^{2+}$-dependent activation of AKT and downregulation of E-cadherin expression [197]. Interestingly, a recent clinical study in patients with stable heart failure found that the novel, first-in-class TRPV4 inhibitor GSK2798745 was well tolerated, suggesting that TRPV4 blockade might be a safe target for metastatic breast cancer [198]. However, conflicting evidence suggests that downregulation of TRPV4 in tumour endothelial cells leads to increased tumour angiogenesis and enhanced tumour growth in vivo [199], and that activation (rather than inhibition) of TRPV4 promotes cell death and inhibits in vivo tumour formation in certain breast cancer cell lines [188]. These contrasting results highlight the challenge with targeting these channels in a heterogeneous tumour, and suggest that TRPV4 can have both pro- and antitumorigenic properties.

Alongside TRPV6 and TRPV4, TRPV2 is a further vanilloid family receptor that has been implicated in cancer progression. Over-expression of TRPV2 in androgen-dependent LNCaP prostate cancer cells led to the induction of invasive markers, matrix metalloproteinases (MMP9) and cathepsin-B [153]. In addition, siRNA silencing of TRPV2 reduced the growth and invasion of PC-3 cells in xenograft models of prostate cancer and reduced the expression of invasive markers, MMP2, MMP9, and cathepsin-B [153], suggesting that inhibition of TRPV2 may reduce the aggressive phenotype of prostate cancer.

Our understanding of how other TRP channels might contribute to cancer progression is more limited. TRPM2 has been implicated in facilitating AKT-dependent migration and tumour formation in gastric cancer cells [200]. Elevated TRPC5 expression has been identified in colon tumours and metastases, where it is correlated with poor prognosis [201]; TRPC5 overexpression in colon cancer cells led to altered intracellular $\mathrm{Ca}^{2+}$ levels, decreased E-cadherin, and promotion of EMT, resulting in increased proliferation and invasion [202]. TRPC6-mediated elevations in $\left[\mathrm{Ca}^{2+}\right]_{\mathrm{i}}$ have been implicated in the development of multi-drug resistance in hepatocellular carcinoma cells [203]. More recent studies have described novel selective TRPC6 inhibitors that demonstrated efficacy in xenograft models of gastric cancer [204]. Furthermore, other TRP channels not yet directly correlated with cancer are known to be involved in mechanotransduction during cell migration, and thus could be involved in metastasis ([205] and Box 4). For example, TRPC1, TRPC2, TRPV1, TRPM3, TRPM4, and TRPA1 are all reported to exhibit mechanosensitivity [47,115]. Furthermore, the heat sensitive TRPV2, expressed in human leukemia cells, is also reported to be mechano-sensitive [111], and TRPP1/TRPP2 are over-expressed in colorectal cancer and facilitate an aggressive phenotype [46]. Therefore, more TRP channels may emerge as attractive therapeutic targets in the future as their role in cancer progression is further delineated.

\subsection{SOCE}

SOCE was first linked to tumour cell migration and metastasis in MDA-MB-231 breast cancer cells, where [135] siRNA-induced silencing of Orai1 or STIM1, or treatment with the SOCE blocker SKF96365, reduced in vitro migration and invasion [135]. Furthermore, Orai1 or STIM1 siRNA and SKF96365 inhibited lung metastasis following tail vein injection of MDA-MB-231 cells into severe combined 
immunodeficient (SCID) mice [135]. The mechanism for the Orai1/STIM1-induced migration and invasive properties was shown to be the result of focal adhesion turnover that was dependent on H-Ras and Rac1 [135]. Since this study, numerous studies have implicated SOCE in migration, EMT, and invasion in a diverse range of malignancies, including gastric cancer [206], colorectal cancer [207,208], melanoma [209], clear cell renal cell carcinoma [124], prostate [210], and hepatocellular carcinoma [211]. Intriguingly, numerous cancer-related Orai mutants have been identified from the cBioPortal tumour database, which result in constitutive $\mathrm{Ca}^{2+}$ entry and NFAT activation [212]. Furthermore, studies suggest that Orai1 can also functionally couple with other channels when promoting migration, with Orai1 in colon cancer cells forming part of a functional channel complex with small conductance $\mathrm{Ca}^{2+}$-activated potassium channel 3 (SK3) and TRPC1 channels to amplify SOCE, AKT activation, and migratory behaviour [213]. A similar association between SK3 and Orai1 has been observed in breast cancer cells, where it is mediated by SigmaR1, a stress-activated chaperone [207]. Interestingly, collagen I (a factor found in the tumour microenvironment) regulates colocalization of Orai1 and the Kv10.1 channel in breast cancer cells to enhance $\mathrm{Ca}^{2+}$ entry and cell survival [214,215], indicating that extracellular matrix factors within the tumour microenvironment can influence ion channel functional coupling to remodel SOCE in cancer cells.

Changes in STIM expression and function have also been implicated in cancer. Gene chip microarray of 295 breast cancer patients revealed a high STIM1 and low STIM2 expression in basal-like tumours that have a particularly poor prognosis and few treatment options. This suggests that the STIM1/STIM2 expression ratio may represent a good prognostic marker for breast cancer [122]. In-addition, STIM1 has been shown to be important for cervical cancer cell proliferation, migration, and angiogenesis [134]. STIM1 expression was up-regulated in $71 \%$ of early stage cervical cancer and the level of expression in primary tumour tissue was linked to the occurrence of pelvic lymph node metastasis and poor patient survival [134]. STIM1 knockdown using shRNA and SOCE blockers (2-APB and SKF96365) reduced cervical cancer growth and the number of tumour blood vessels in cervical cancer xenograft mouse models [134]. This STIM1-induced migration was owing to $\mathrm{Ca}^{2+}$-dependent calpain and PYK2-mediated focal adhesion turnover, and the increase in angiogenesis was owing to STIM1-dependent secretion of VEGF from cervical cancer cells [134]. Conversely, in colorectal cancer cells, STIM1 regulates migration by stimulating the production of cyclooxygenase- 2 and production of prostaglandin E2 [216].

Collectively, the above studies suggest that STIM1 and Orai1 represent good therapeutic targets and inhibitors of SOCE may reduce cancer cell proliferation, migration, invasion, and tumour angiogenesis. Indeed, novel SOCE blockers currently under development by CalciMedica and Rhizen Pharmaceuticals for other indications could be repurposed for cancer if successful. However, the ubiquitous nature of these proteins raises the possibility of adverse effects, regardless of the specificity of such drugs. Indeed, reduced Orai1 and STIM1 expression leads to apoptosis resistance in prostate cancer cells, presumably owing to reduced global $\mathrm{Ca}^{2+}$ overload [127], suggesting that prolonged pharmacological inhibition of SOCE would also likely lead to resistance to apoptosis. Thus, it remains to be determined whether any therapeutic benefit of blocking SOCE outweighs the detrimental effects of promoting apoptosis resistance.

\subsection{Store-Independent Arachinodate-Regulated $\mathrm{Ca}^{2+}$ Channels (ARC)}

In addition to the widely studied Orai1 and STIM1, there are additional isoforms including Orai2, Orai3, and Stim 2 that contribute to SOCE $[217,218]$. Recent evidence shows that Orai3 is up-regulated in breast [123,129-131], lung [133], and prostate cancer [132], and contributes to tumorigenesis [129,130]. Furthermore, it has recently been discovered that the store-independent, arachidonate-regulated $\mathrm{Ca}^{2+}$ entry channel (ARC) [219] consists of heteropentameric subunits of Orai1 and Orai3 [220] (Box 6). 
Box 6. Arachidonate-Regulated $\mathrm{Ca}^{2+}$ Channels (ARC).

- $\quad$ ARC is a store-independent, arachidonate-regulated $\mathrm{Ca}^{2+}$ entry channel (ARC) [219]

- $\quad$ ARC consists of heteropentameric subunits of Orai1 and Orai3 [220]

- ARC has similar molecular composition and biophysical characteristics to SOCE channels [219]

- $\quad$ Activation of ARC requires plasma membrane STIM1, rather than ER STIM1 [219]

- $\mathrm{Ca}^{2+}$ entry through ARC channels controls the frequency of $\mathrm{Ca}^{2+}$ oscillations

- $\quad \mathrm{Ca}^{2+}$ entry through ARC channels activates PLC- $\delta$ and increases $\mathrm{IP}_{3}$ production [221]

Therefore, the contribution of Orai3 in tumorigenesis could be owing to increased ARC channels. Indeed, it has been reported that the relative proportions of Orai proteins are altered in prostate cancer, compared with non-cancerous tissue, with a particularly up-regulated Orai3 expression [126]. Mimicking this up-regulated Orai3 expression in PC3 prostate cancer cell lines led to an increase in characteristic ARC-mediated, store-independent $\mathrm{Ca}^{2+}$ entry, and a consequent increase in NFAT-mediated cell proliferation [126]. A more recent study showed that arachidonic acid (AA) (or arachidonate)-regulated $\mathrm{Ca}^{2+}$-entry (ARC) induces migration in $\mathrm{BON}$ gastroenteropancreatic neuroendocrine tumour cells [222]. In addition, in xenograft models of prostate cancer, siRNA knockdown of Orai3 dramatically reduced tumour growth [126]. The authors speculated that the increase in Orai3 expression and/or change in the tumour microenvironment (arachidonic acid) led to the recruitment of Orai1 subunits into the assembly of heteropentameric Orai1/Orai3 ARC channels (Figure 5). In addition to increasing the ARC-mediated NFAT-dependent cell proliferation, this led to the reduction of Orai1 subunits for the assembly of homotetrameric Orai1-containing SOCE channels and the consequent apoptosis resistance [126] (Figure 5).

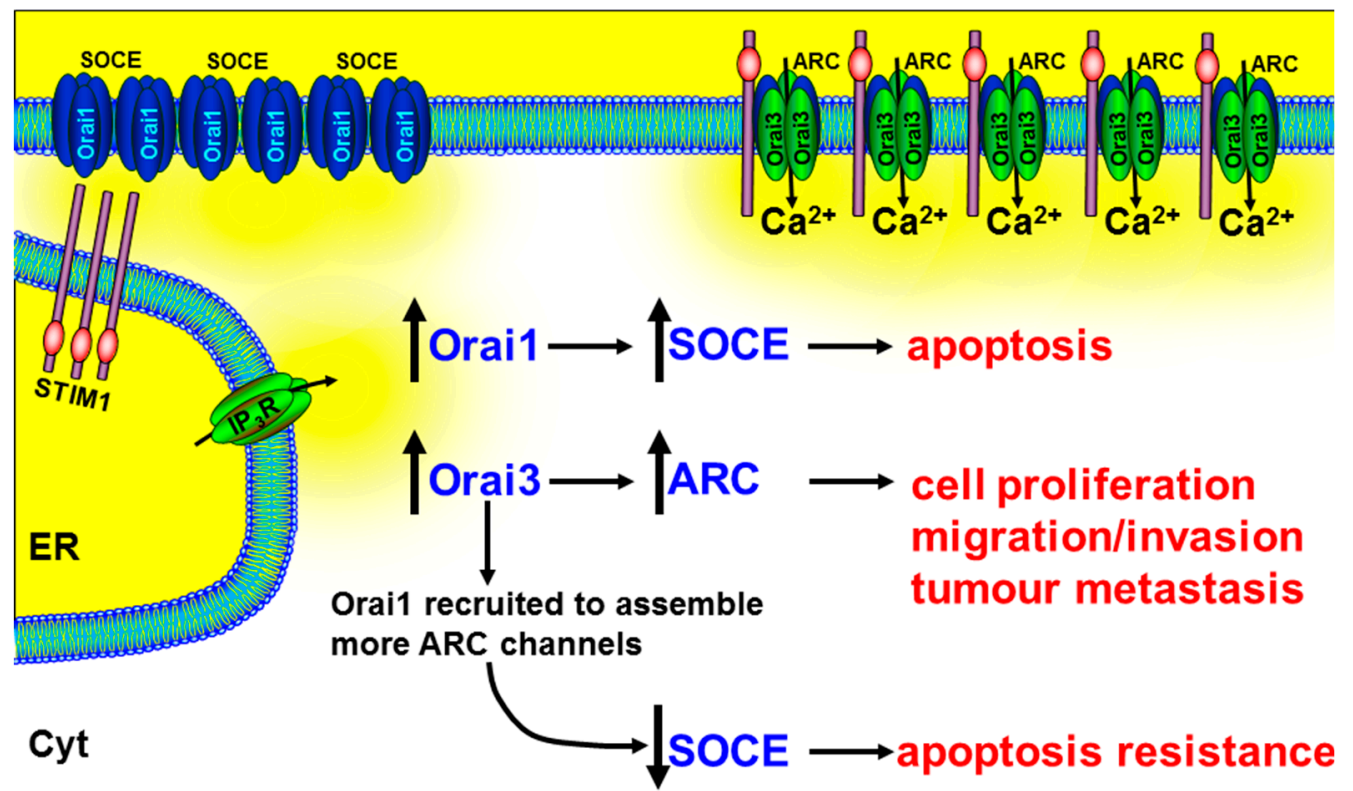

Figure 5. The role of Orai3 and ARC channels in numerous cancer hallmark responses. Arachidonate-regulated $\mathrm{Ca}^{2+}$ entry channels (ARC) consist of heteropentameric subunits of Orai1 and Orai3. The increase in Orai3 expression and/or change in the tumour microenvironment (arachidonic acid) lead to the recruitment of Orai1 subunits into the assembly of heteropentameric Orai1/Orai3 ARC channels and a corresponding decrease in available Orai1 subunits for the assembly of SOCE channels. The increase in the ARC channels leads to the NFAT-dependent cell proliferation, migration/invasion, and tumour metastasis, and the reduction in SOCE leads to apoptosis resistance. This suggests that drugs designed to specifically inhibit Orai3, or their assembly with Orai1, might inhibit tumour growth and metastasis, while simultaneously promoting apoptosis. 
Another important feature of ARC channels is the regulation by plasma membrane STIM1 rather than ER STIM1 [219]. There is extensive evidence for the critical role of ER STIM1 in regulating SOCE. However, it is worth remembering that, prior to the discovery of the role of STIM1 in SOCE in 2005 [12,223], STIM1 was first identified in a screen for cell adhesion molecules [224], as its name suggests (stromal interacting molecule 1). Moreover, arachidonic acid is generated by activation of various growth factors [225] and has been implicated in the migration of breast cancer cells via FAK phosphorylation [226]. It is thus tempting to speculate that plasma membrane STIM1 and ARC channels may be important in cancer migration by sensing the tumour microenvironment. This could dramatically elevate the importance of ARC channels from relative obscurity to a critical role in cancer progression.

\subsection{Secretory Pathway $\mathrm{Ca}^{2+}$-ATPase (SPCA)}

Another way in which $\mathrm{Ca}^{2+}$ entry through Orai1 can be activated independent of STIM1 and store depletion is by the interaction of the secretory pathway ATPase-2 (SPCA2) with Orai1 in the plasma membrane, which was recently discovered to promote breast tumorigenesis [227]. The SPCA is expressed on the golgi and is important for the transport of $\mathrm{Ca}^{2+}$ and $\mathrm{Mn}^{2+}$ into the golgi lumen. These ions are important for the correct processing of newly synthesized proteins in the secretory pathway [228]. Evidence from breast cancer cell lines suggests that SPCA transporters might be the initiator of microcalcifications within breast tumours that correlate with tumour progression [229]. In basal-like breast cancer cells, SPCA1 is up-regulated and leads to an increase in the processing and trafficking of the insulin-like growth factor receptor (IGF-1R), which ultimately leads to an increased growth and proliferative phenotype [230]. This is perhaps not surprising when one considers that the normal function of SPCA is to regulate the synthesis and processing of proteins within the secretory pathway. However, SPCA2 is over-expressed in the plasma membrane of breast cancer cells, where it directly binds to and activates Orai1, independent of STIM1, and leads to enhanced $\mathrm{Ca}^{2+}$ entry and $\mathrm{Ca}^{2+}$-dependent proliferation [227]. Specifically, silencing SPCA2 in breast cancer cell lines reduced resting $\mathrm{Ca}^{2+}$, cell proliferation, anchorage-dependent growth, and breast tumour growth in mouse xenograft models, whereas over-expression of SPCA2 had opposite effects [227]. Interestingly, over-expression of a mutant SPCA2 without any ATPase activity also increased resting $\mathrm{Ca}^{2+}$ and anchorage-dependent growth, similar to the wild type SPCA2. This, therefore, suggests that the tumorigenic effects of SPCA2 were independent of its $\mathrm{Ca}^{2+}$-ATPase activity. Immunofluorescence and cell surface biotinylation assays revealed that SPCA2 partially localized to the plasma membrane and associated with the N-terminal domain of Orai1, where it directly regulated $\mathrm{Ca}^{2+}$ entry, led to the nuclear translocation of NFAT and increased cell proliferation. This mechanism is potentially an important drug target in malignant breast lesions, as SPCA is not normally expressed in the plasma membrane of normal cells. Therefore, targeting SPCA might be an effective therapeutic strategy for specifically treating breast cancer. Whether this SPCA2-Orai interaction and novel store-independent $\mathrm{Ca}^{2+}$ entry pathway are important in other types of cancer remains to be determined.

\subsection{PMCA}

PMCA has been shown to have an important role in cancer $[157,158,231]$. Overexpression of PMCA4 in PDAC correlates with poor prognosis, while siRNA knockdown of PMCA4 inhibited migration and apoptosis resistance in cultured PDAC cells [232]. In the breast, PMCA has an important role in the normal physiology and in tumorigenesis. PMCA2 is up-regulated during lactation and controls milk production in normal mammary epithelial cells, but is then down-regulated during weaning when the secretory cells die from apoptosis [233]. This loss of PMCA2 expression is thought to elevate resting cytosolic $\mathrm{Ca}^{2+}$, thereby increasing the sensitivity of $\mathrm{Ca}^{2+}$-dependent apoptosis [158] (Figure 3). In breast cancer, PMCA2 expression increases significantly; this eventually leads to resistance to apoptosis and is thought to contribute to tumorigenesis [158]. More recent studies have shown that, specifically, PMCA2 remodels $\left[\mathrm{Ca}^{2+}\right]_{i}$ in breast cancer cells to facilitate continued HER2 biochemical signalling and 
PMCA2 knock out inhibits the formation of tumours in vivo [234]. However, direct inhibition of the PMCA is unlikely to be feasible as a therapeutic strategy owing to its ubiquitous expression. Targeting the pathophysiological coupling between calcium transporters and their downstream effectors might be a more subtle approach that would avoid toxicity.

\section{Metabolic Regulation of the $\mathrm{Ca}^{2+}$ Transporters}

Aberrant metabolism is a hallmark of cancer [235], with many transformed cells exhibiting a dramatic increase in glycolytic metabolism (the 'Warburg effect') that is key to maintaining a highly proliferative, pro-survival, and invasive cancer phenotype [236]. Remodelling of $\mathrm{Ca}^{2+}$ signalling is known to influence metabolic changes in cancer cells that in turn promote aggressive behaviour; for example, expression of MCU correlates with tumour size and metastasis in triple negative breast cancer, with evidence implicating mitochondrial $\mathrm{Ca}^{2+}$ uptake in promoting $\mathrm{HIF}-1 \alpha$ expression and invasiveness [237]. On the other hand, metabolism and the generation of ATP have a strong influence on $\mathrm{Ca}^{2+}$ signalling, and while cancer metabolism has been previously targeted for therapeutic intervention, as reviewed extensively elsewhere $[238,239]$, the relationship between altered metabolism in cancer and its regulation of $\mathrm{Ca}^{2+}$ signalling remains relatively unexplored. Indeed, an alternative strategy to directly targeting the $\mathrm{Ca}^{2+}$ signalling machinery is to instead target those metabolic processes that regulate $\mathrm{Ca}^{2+}$ signalling, but are altered following metabolic transformation, thereby providing a means to selectively target malignant cells. Two of the main controllers of $\left[\mathrm{Ca}^{2+}\right]_{i}$ homeostasis are the ATP-dependent $\mathrm{Ca}^{2+}$ pumps, PMCA and SERCA. These pumps are responsible for the maintenance of a low resting $\left[\mathrm{Ca}^{2+}\right]_{\mathrm{i}}$, and are inextricably linked to cell metabolism owing to their requirement for a robust supply of ATP [240]. Impairment of either PMCA or SERCA can lead to compromised $\left[\mathrm{Ca}^{2+}\right]_{\mathrm{i}}$ homeostasis with catastrophic consequences for any cell [241]. In many non-excitable cells, NCX is either absent or not functional; the PMCA is thus critical for $\mathrm{Ca}^{2+}$ efflux and its failure results in an inability to maintain a low resting $\left[\mathrm{Ca}^{2+}\right]_{i}$, resulting in $\left[\mathrm{Ca}^{2+}\right]_{i}$ overload and cell death $[76,79,240]$. Of relevance to cancer, the PMCA is critically reliant on glycolytically-derived ATP in pancreatic cancer cells exhibiting a highly glycolytic phenotype, with inhibition of glycolysis in these cells leading to ATP depletion, PMCA inhibition, $\mathrm{Ca}^{2+}$ overload, and ultimately necrotic cell death [242-245].

Evidence also suggests that the PMCA may be fuelled by a local, submembrane supply of glycolytically-derived ATP. Studies using inside-out smooth muscle plasma membrane vesicles established that glycolytic enzymes associate with the plasma membrane, thereby providing a submembrane pool of glycolytically-derived ATP to fuel the PMCA [246]. Extensions of this study indicate that PMCA preferentially uses ATP produced by these membrane-bound enzymes to fuel $\mathrm{Ca}^{2+}$ transport [247]. Silencing phosphofructokinase fructose bisphosphatase-3 (PFKFB3) at the membrane of endothelial cells prevents the generation of a sub-membrane glycolytic ATP pool and inhibits migration [248]. These findings highlight the broader potential importance of a sub-membrane glycolytic cascade in cell migration that could be extrapolated to cancer. More recent studies have determined that glycolytic enzymes, including PFKFB3 and the M2 isoform of pyruvate kinase (PKM2), associate with the plasma membrane in pancreatic cancer cell lines [244]. Moreover, specific pharmacological inhibition of either PKM2 [244] or PFKFB3 [245] inhibited PMCA activity, resulting in inhibition of migration and cytotoxic calcium overload. Given the aberrant changes in glycolytic enzyme expression prevalent in cancer cells, it is tempting to speculate that a privileged glycolytic ATP supply to $\mathrm{Ca}^{2+}$ pumps may be an untapped novel therapeutic locus. Owing to the aberrant expression of PFKFB3 and PKM2 in cancer cells compared with their corresponding "normal" cell counterparts, targeting these glycolytic enzymes might provide a means to target $\mathrm{Ca}^{2+}$ pumps specifically in cancer cells.

\section{Calcium Signalling and the Tumour Immune Microenvironment}

Beyond targeting $\mathrm{Ca}^{2+}$ signalling within cancer cells themselves, the tumour immune microenvironment offers an additional rich tapestry of potential targets for therapeutic intervention. 
Tumour-infiltrating immune cells exhibit their own repertoire of $\mathrm{Ca}^{2+}$ signalling machinery that has critical roles in their respective anti-tumour or pro-tumour functions. Moreover, the specific spatiotemporal pattern of $\mathrm{Ca}^{2+}$ signalling can differentially encode gene expression and cell fate in immune cells $[5,6]$. These immune cells include antigen-presenting dendritic cells (DCs), cytotoxic CD8+ T lymphocytes (CTLs), natural killer (NK) cells, type 1 and type 2 CD4+ T helper cells (Th1 and Th2), CD4+ regulatory T cells (Tregs), B lymphocytes, M1- and M2-like tumour-associated macrophages (TAMs), tumour-associated neutrophils (TANs), and myeloid-derived suppressor cells (MDSCs). Within any given tumour microenvironment, there is a balance between the "anti-tumour" activities of DCs, CTLs, NK cells, Th1 cells, and M1-TAMs, which cooperate to kill cancer cells, and the pro-tumour activities of M2-TAMs, Th2 cells, B cells, Tregs, and MDSCs, which simultaneously promote tumour progression and immune evasion [249-251]. This balance can vary dramatically depending on the tumour-type. It can also dynamically change during tumour progression from primary through to secondary metastasis and is inextricably linked to the inflammatory environment [249]. For example, many solid tumours (e.g., pancreatic, colon) are largely devoid of CTLs at the core of the tumour owing to the presence of TAMs, which secrete cytokines (interleukin-10 (IL10), TGF $\beta$ ) that inhibit DC maturation and dampen effector T cell activity and infiltration [249]. As the tumour progresses, the number of immunosuppressive M2-like TAMs increases, which in turn promotes tumour progression by secreting EGF, VEGF, and MMPs; these factors promote cancer cell proliferation, angiogenesis, and invasion and a pre-metastatic niche, respectively. The authors would like to refer the reader to the following review articles that summarise some of the key properties of tumour infiltrating immune cells and the mechanisms behind immunosurveillance [249-251].

Of relevance to the current article, $\mathrm{Ca}^{2+}$ signalling is critical for almost every aspect of immune cell function, and most of these cells are particularly dependent on CRAC channel function [252-255]. For example, $\mathrm{Ca}^{2+}$ entry through CRAC channels in CTLs and NK cells is critical for their cytolytic immune cell functions [256]. Following formation of the immune synapse between the target cancer cell and the immune cell, antigen recognition and $\mathrm{T}$ cell receptor signaling trigger a CRAC-dependent increase in intracellular $\mathrm{Ca}^{2+}$ that stimulates lytic granule release proximal to the target cell [257]. Therefore, in addition to their opposing roles in proliferation/migration/invasion and apoptosis in cancer cells, CRAC channels have a further additional role in regulating immune surveillance and tumour elimination by immune cells.

Therefore, the critical role played by CRAC channels in immune cell function brings into question the potential benefits of CRAC/Orai channel inhibitors in reducing tumour growth, as proposed by numerous groups in the field $[92,134,135,210,227,258,259]$. This is because the putative therapeutic effects of CRAC/Orai blockers on cancer cells might be counteracted by a concomitant inhibitory effect on tumour-associated immune cells; CRAC/Orai blockade might be expected to reduce CTL and NK cell activity, thereby compromising the anti-tumour immune response. However, a recent study showed that CTLs and NK cells have a bell-shaped $\mathrm{Ca}^{2+}$-dependence with respect to cancer cell killing and lytic granule release [260]. In particular, CTLs have a very low optimum cytosolic $\mathrm{Ca}^{2+}$ $(122-334 \mathrm{nM})$ and external $\mathrm{Ca}^{2+}(23-625 \mu \mathrm{M})$ dependency for efficient cancer cell elimination, the latter being well below the typical blood plasma $\mathrm{Ca}^{2+}$ concentration. While this raises questions as to the physiological relevance of CRAC/Orai channels in this response, it also suggests that partial inhibition of CRAC/Orai-linked $\mathrm{Ca}^{2+}$ signalling might actually be beneficial by shifting the $\mathrm{Ca}^{2+}$-dependency towards an optimum lytic granule release, and thus facilitate a more efficient cancer cell killing response by CTLs. Clearly, further research is required to fully characterize the effects of CRAC/Orai blockade on the immune response within tumours in vivo.

Paradoxically, some elements of the tumour-associated immune response can also facilitate tumour progression rather than combat it. This phenomenon could be at least in part attributable to changes in $\mathrm{Ca}^{2+}$ signalling dynamics, either within cancer cells or within the immune cells. For example, cytokines released by immune cells can induce changes in $\mathrm{Ca}^{2+}$ signalling within cancer cells, leading to migratory and invasive behaviour. Release of the inflammatory regulator $\mathrm{C}-\mathrm{C}$ motif chemokine 
18 [261] by TAMs stimulates $\mathrm{Ca}^{2+}$ signalling and facilitates migration of MDA-MB-231 breast cancer cells [262]. In this study, CCL18 release from TAMs led to activation of their putative cell surface receptor, phosphatidylinositol transfer protein membrane-associated 3 (PITPNM3; otherwise known as PYK2 N-terminal domain-interacting receptor 1, Nir1), which in turn phosphorylated PLC $\gamma 1$ and PKC $\zeta$, activated IP3 kinase B1 (IP3KB1), and induced $\mathrm{Ca}^{2+}$ signalling. Importantly, CCL18 expression correlated with invasive behaviour and poor survival in patients with breast cancer. Similarly, release of the inflammatory chemokine C-C motif chemokine 5 (CCL-5) from TAMs induced migration of glioma cells in a process dependent on increases in cytosolic $\left[\mathrm{Ca}^{2+}\right]$ and phosphorylation of CaMKII [263]. Indeed, CCL-5 has previously been implicated in invasive behaviour and metastasis in a range of tumours, including prostate, bone, and breast cancers [264].

On the other hand, evidence suggests that tumour cells can 'hijack' $\mathrm{Ca}^{2+}$ signalling within immune cells to enable evasion from the anti-tumour immune response. Prostaglandin E2 produced by MCF7 breast cancer cells stimulated upregulation of SERCA3 expression in CD4+ T cells, leading to ER stress and CD4+ T cell apoptosis [265]. Interestingly, the dihydropyrimidone derivative nifetepimine induced downregulation of SERCA3 expression, thereby protecting CD4+ T cells from tumour cell-induced cytotoxicity.

It is also important to note that the tumour microenvironment is notoriously highly acidic, owing to the highly glycolytic phenotype and increased lactic acid efflux exhibited by cancer cells [266]. This acidic microenvironment not only facilitates matrix remodelling, and thus migration/invasion [267], but also has a profound inhibitory effect on immune surveillance [251]. Specifically, tumour acidity inhibits the cancer cell killing properties of CTLs, NK cells, and antigen-presenting DCs, while simultaneously promoting the immunosuppressive properties of Tregs, myeloid cells, and TAMs [251]. This is particularly relevant because almost every $\mathrm{Ca}^{2+}$ channel/transporter is exquisitely sensitive to pH, especially CRAC channels [268,269], and the acid-sensing $\mathrm{Ca}^{2+}$-permeable ion channels (ASICs) have important roles in both cancer cells [270-273] and immune cells [274-276]. Moreover, the acidic tumour microenvironment would be expected to impact $\mathrm{Ca}^{2+}$-signalling in both cancer cells [232] and immune cells $[277,278]$ by promoting PMCA activity. This is because ATP-driven PMCAs are $\mathrm{Ca}^{2+} / \mathrm{H}^{+}$ exchangers, and thus their $\mathrm{Ca}^{2+}$ efflux activity is facilitated by extracellular acidification and inhibited by extracellular alkalinisation $[279,280]$. Therefore, in addition to providing a privileged ATP supply to PMCAs, the highly glycolytic cancer cell phenotype would provide an abundance of extracellular $\mathrm{H}^{+}$ions with which to accentuate PMCA activity, potentially enhancing apoptosis resistance in cancer cells or altering immune cell function. This means that any novel and specific PMCA inhibitors may be especially effective as a combination therapy with drugs that target aberrant tumour metabolism or tumour acidification. These include glycolytic inhibitors [244], lactic acid/monocarboxylate transporter (MCT) inhibitors [281], lactate dehydrogenase (LDH) inhibitors [282,283], or hypoxia inducible factor (HIF1 $\alpha$ ) inhibitors [284]. In addition, these drugs may also have a synergistic effect when combined with other novel immunotherapies such as immune checkpoint inhibitors [285].

While we currently have only a limited understanding of how immune response-related $\mathrm{Ca}^{2+}$ signalling is altered in cancer, these studies suggest that $\mathrm{Ca}^{2+}$ signalling modulators might find utility in ameliorating the dampened immune response observed in many tumours; at present, this is a burgeoning field that warrants further investigation.

\section{Conclusions}

It is clear that cytosolic $\mathrm{Ca}^{2+}$ signalling is central to the major hallmark processes of the cancer phenotype, including limitless replicative capacity, uncontrolled cell proliferation, resistance to apoptosis, tissue invasion, and angiogenesis, as well as immune surveillance [1]. Given that many of the mainstay anti-cancer drugs remain largely ineffective for many cancers, emerging scientific evidence points to the $\mathrm{Ca}^{2+}$ signalling machinery as a rich tapestry of novel putative therapeutic targets. Leading candidates include TRP channels, ARC channels (Orai3 and plasma membrane STIM1), plasma membrane SPCA2, and SOCE channels (ER STIM1 and Orai1). However, the ubiquitous 
nature of many $\mathrm{Ca}^{2+}$ channels and transporters means that targeting them with novel therapeutics may produce unacceptable adverse effects. This is especially true for SOCE, in which pharmacological blockade may successfully inhibit cell proliferation, migration, and invasion, but will potentially also lead to apoptosis resistance and facilitate immune evasion, while inhibiting critical functions in normal cells. Therefore, the ideal strategy is to target $\mathrm{Ca}^{2+}$ channels, or regulatory proteins or processes, that are either uniquely expressed or their expression results in an entirely new function in cancer cells. The latter seems to be certainly true for the plasma membrane SPCA2-mediated regulation of Orai1, which appears to be a unique property of breast cancer cells. Likewise, targeting the glycolytic ATP fuelling of the PMCA may also represent an effective therapeutic strategy for selectively targeting cancer cells. Nevertheless, many of the studies described in this review represent early stage basic science research, and thus it remains to be determined whether targeting these candidate proteins will be therapeutically effective in clinical studies of the human disease.

Author Contributions: Both authors (J.I.E.B and A.D.J.) contributed equally to the original literature research, original drafting of specific sections, review, editing and proof reading. Figures were generated by J.I.E.B. All authors have read and agreed to the published version of the manuscript.

Funding: This work was funded by a Pancreatic Cancer Research Fund (PCRF) grant and Medical Research Council (MRC) grant (MR/P00251X/1).

Conflicts of Interest: The authors declare no conflict of interest.

\section{References}

1. Martinac, B. The ion channels to cytoskeleton connection as potential mechanism of mechanosensitivity. Biochim. Biophys Acta 2014, 1838, 682-691. [CrossRef] [PubMed]

2. Stevens, E.A.; Rodriguez, C.P. Genomic medicine and targeted therapy for solid tumors. J. Surg. Oncol. 2014. [CrossRef] [PubMed]

3. Berridge, M.J. Calcium signalling remodelling and disease. Biochem. Soc. Trans. 2012, 40, 297-309. [CrossRef] [PubMed]

4. Jaggar, J.H.; Porter, V.A.; Lederer, W.J.; Nelson, M.T. Calcium sparks in smooth muscle. Am. J. Physiol. Cell Physiol. 2000, 278, C235-C256. [CrossRef] [PubMed]

5. Dolmetsch, R.E.; Xu, K.; Lewis, R.S. Calcium oscillations increase the efficiency and specificity of gene expression. Nature 1998, 392, 933-936. [CrossRef]

6. Li, W.; Llopis, J.; Whitney, M.; Zlokarnik, G.; Tsien, R.Y. Cell-permeant caged InsP3 ester shows that Ca ${ }^{2+}$ spike frequency can optimize gene expression. Nature 1998, 392, 936-941. [CrossRef]

7. Fedorenko, O.A.; Popugaeva, E.; Enomoto, M.; Stathopulos, P.B.; Ikura, M.; Bezprozvanny, I. Intracellular calcium channels: Inositol-1,4,5-trisphosphate receptors. Eur. J. Pharmacol. 2013. [CrossRef]

8. Mikoshiba, K. The IP3 receptor/Ca ${ }^{2+}$ channel and its cellular function. Biochem. Soc. Symp. 2007, 9-22. [CrossRef]

9. Galione, A.; Chuang, K.T. Pyridine nucleotide metabolites and calcium release from intracellular stores. Adv. Exp. Med. Biol. 2012, 740, 305-323. [CrossRef]

10. Putney, J.W., Jr. A model for receptor-regulated calcium entry. Cell Calcium 1986, 7, 1-12. [CrossRef]

11. Vig, M.; Peinelt, C.; Beck, A.; Koomoa, D.L.; Rabah, D.; Koblan-Huberson, M.; Kraft, S.; Turner, H.; Fleig, A.; Penner, R.; et al. CRACM1 is a plasma membrane protein essential for store-operated $\mathrm{Ca}^{2+}$ entry. Science 2006, 312, 1220-1223. [CrossRef] [PubMed]

12. Zhang, S.L.; Yu, Y.; Roos, J.; Kozak, J.A.; Deerinck, T.J.; Ellisman, M.H.; Stauderman, K.A.; Cahalan, M.D. STIM1 is a $\mathrm{Ca}^{2+}$ sensor that activates CRAC channels and migrates from the $\mathrm{Ca}^{2+}$ store to the plasma membrane. Nature 2005, 437, 902-905. [CrossRef] [PubMed]

13. Yeromin, A.V.; Zhang, S.L.; Jiang, W.; Yu, Y.; Safrina, O.; Cahalan, M.D. Molecular identification of the CRAC channel by altered ion selectivity in a mutant of Orai. Nature 2006, 443, 226-229. [CrossRef] [PubMed]

14. Wu, L.J.; Sweet, T.B.; Clapham, D.E. International Union of Basic and Clinical Pharmacology. LXXVI. Current progress in the mammalian TRP ion channel family. Pharmacol. Rev. 2010, 62, 381-404. [CrossRef] [PubMed]

15. Caterina, M.J.; Schumacher, M.A.; Tominaga, M.; Rosen, T.A.; Levine, J.D.; Julius, D. The capsaicin receptor: A heat-activated ion channel in the pain pathway. Nature 1997, 389, 816-824. [CrossRef] 
16. Stowers, L.; Holy, T.E.; Meister, M.; Dulac, C.; Koentges, G. Loss of sex discrimination and male-male aggression in mice deficient for TRP2. Science 2002, 295, 1493-1500. [CrossRef]

17. Sumoza-Toledo, A.; Penner, R. TRPM2: A multifunctional ion channel for calcium signalling. J. Physiol. 2011, 589, 1515-1525. [CrossRef]

18. Strehler, E.E. Plasma membrane calcium ATPases as novel candidates for therapeutic agent development. J. Pharm. Pharm. Sci. 2013, 16, 190-206. [CrossRef]

19. Vandecaetsbeek, I.; Vangheluwe, P.; Raeymaekers, L.; Wuytack, F.; Vanoevelen, J. The Ca ${ }^{2+}$ pumps of the endoplasmic reticulum and Golgi apparatus. Cold Spring Harb. Perspect. Biol. 2011, 3, a004184. [CrossRef]

20. Khananshvili, D. The SLC8 gene family of sodium-calcium exchangers (NCX)-structure, function, and regulation in health and disease. Mol. Aspects Med. 2013, 34, 220-235. [CrossRef]

21. Patron, M.; Raffaello, A.; Granatiero, V.; Tosatto, A.; Merli, G.; De Stefani, D.; Wright, L.; Pallafacchina, G.; Terrin, A.; Mammucari, C.; et al. The mitochondrial calcium uniporter (MCU): Molecular identity and physiological roles. J. Biol. Chem. 2013, 288, 10750-10758. [CrossRef] [PubMed]

22. Hogan, P.G.; Chen, L.; Nardone, J.; Rao, A. Transcriptional regulation by calcium, calcineurin, and NFAT. Genes Dev. 2003, 17, 2205-2232. [CrossRef] [PubMed]

23. Schneider, G.; Oswald, F.; Wahl, C.; Greten, F.R.; Adler, G.; Schmid, R.M. Cyclosporine inhibits growth through the activating transcription factor/cAMP-responsive element-binding protein binding site in the cyclin D1 promoter. J. Biol. Chem. 2002, 277, 43599-43607. [CrossRef] [PubMed]

24. Rasmussen, C.D.; Means, A.R. Calmodulin is required for cell-cycle progression during G1 and mitosis. EMBO J. 1989, 8, 73-82. [CrossRef]

25. Takuwa, N.; Zhou, W.; Kumada, M.; Takuwa, Y. $\mathrm{Ca}^{2+}$-dependent stimulation of retinoblastoma gene product phosphorylation and p34cdc2 kinase activation in serum-stimulated human fibroblasts. J. Biol. Chem. 1993, 268, 138-145.

26. Kupzig, S.; Walker, S.A.; Cullen, P.J. The frequencies of calcium oscillations are optimized for efficient calcium-mediated activation of Ras and the ERK/MAPK cascade. Proc. Natl. Acad. Sci. USA 2005, 102, 7577-7582. [CrossRef]

27. Dolmetsch, R.E.; Pajvani, U.; Fife, K.; Spotts, J.M.; Greenberg, M.E. Signaling to the nucleus by an L-type calcium channel-calmodulin complex through the MAP kinase pathway. Science 2001, 294, 333-339. [CrossRef]

28. Rosen, L.B.; Ginty, D.D.; Weber, M.J.; Greenberg, M.E. Membrane depolarization and calcium influx stimulate MEK and MAP kinase via activation of Ras. Neuron 1994, 12, 1207-1221. [CrossRef]

29. Liu, Q.; Walker, S.A.; Gao, D.; Taylor, J.A.; Dai, Y.F.; Arkell, R.S.; Bootman, M.D.; Roderick, H.L.; Cullen, P.J.; Lockyer, P.J. CAPRI and RASAL impose different modes of information processing on Ras due to contrasting temporal filtering of $\mathrm{Ca}^{2+}$. J. Cell Biol. 2005, 170, 183-190. [CrossRef]

30. Walker, S.A.; Kupzig, S.; Bouyoucef, D.; Davies, L.C.; Tsuboi, T.; Bivona, T.G.; Cozier, G.E.; Lockyer, P.J.; Buckler, A.; Rutter, G.A.; et al. Identification of a Ras GTPase-activating protein regulated by receptor-mediated $\mathrm{Ca}^{2+}$ oscillations. EMBO J. 2004, 23, 1749-1760. [CrossRef]

31. Roderick, H.L.; Cook, S.J. Ca ${ }^{2+}$ signalling checkpoints in cancer: Remodelling $\mathrm{Ca}^{2+}$ for cancer cell proliferation and survival. Nat. Rev. Cancer 2008, 8, 361-375. [CrossRef] [PubMed]

32. Gwack, Y.; Feske, S.; Srikanth, S.; Hogan, P.G.; Rao, A. Signalling to transcription: Store-operated $\mathrm{Ca}^{2+}$ entry and NFAT activation in lymphocytes. Cell Calcium 2007, 42, 145-156. [CrossRef] [PubMed]

33. Lehen'kyi, V.; Flourakis, M.; Skryma, R.; Prevarskaya, N. TRPV6 channel controls prostate cancer cell proliferation via $\mathrm{Ca}^{2+}$ /NFAT-dependent pathways. Oncogene 2007, 26, 7380-7385. [CrossRef] [PubMed]

34. Thebault, S.; Flourakis, M.; Vanoverberghe, K.; Vandermoere, F.; Roudbaraki, M.; Lehen'kyi, V.; Slomianny, C.; Beck, B.; Mariot, P.; Bonnal, J.L.; et al. Differential role of transient receptor potential channels in $\mathrm{Ca}^{2+}$ entry and proliferation of prostate cancer epithelial cells. Cancer Res. 2006, 66, 2038-2047. [CrossRef]

35. Rosenberger, S.; Thorey, I.S.; Werner, S.; Boukamp, P. A novel regulator of telomerase. S100A8 mediates differentiation-dependent and calcium-induced inhibition of telomerase activity in the human epidermal keratinocyte line HaCaT. J. Biol. Chem. 2007, 282, 6126-6135. [CrossRef]

36. Orrenius, S.; Zhivotovsky, B.; Nicotera, P. Regulation of cell death: The calcium-apoptosis link. Nat. Rev. Mol. Cell Biol. 2003, 4, 552-565. [CrossRef]

37. Hardwick, J.M.; Soane, L. Multiple functions of BCL-2 family proteins. Cold Spring Harb. Perspect. Biol. 2013, 5, a008722. [CrossRef] 
38. Datta, S.R.; Ranger, A.M.; Lin, M.Z.; Sturgill, J.F.; Ma, Y.C.; Cowan, C.W.; Dikkes, P.; Korsmeyer, S.J.; Greenberg, M.E. Survival factor-mediated BAD phosphorylation raises the mitochondrial threshold for apoptosis. Dev. Cell 2002, 3, 631-643. [CrossRef]

39. Eskes, R.; Desagher, S.; Antonsson, B.; Martinou, J.C. Bid induces the oligomerization and insertion of Bax into the outer mitochondrial membrane. Mol. Cell. Biol. 2000, 20, 929-935. [CrossRef]

40. Cory, S.; Adams, J.M. The Bcl2 family: Regulators of the cellular life-or-death switch. Nat. Rev. Cancer 2002, 2, 647-656. [CrossRef]

41. Yang, E.; Zha, J.; Jockel, J.; Boise, L.H.; Thompson, C.B.; Korsmeyer, S.J. Bad, a heterodimeric partner for Bcl-XL and Bcl-2, displaces Bax and promotes cell death. Cell 1995, 80, 285-291. [CrossRef]

42. Zha, J.; Harada, H.; Yang, E.; Jockel, J.; Korsmeyer, S.J. Serine phosphorylation of death agonist BAD in response to survival factor results in binding to 14-3-3 not BCL-X(L). Cell 1996, 87, 619-628. [CrossRef]

43. Wang, H.G.; Pathan, N.; Ethell, I.M.; Krajewski, S.; Yamaguchi, Y.; Shibasaki, F.; McKeon, F.; Bobo, T.; Franke, T.F.; Reed, J.C. $\mathrm{Ca}^{2+}$-induced apoptosis through calcineurin dephosphorylation of BAD. Science 1999, 284, 339-343. [CrossRef] [PubMed]

44. Adams, J.M.; Cory, S. The Bcl-2 protein family: Arbiters of cell survival. Science 1998, 281, 1322-1326. [CrossRef] [PubMed]

45. Lizcano, J.M.; Morrice, N.; Cohen, P. Regulation of BAD by cAMP-dependent protein kinase is mediated via phosphorylation of a novel site, Ser155. Biochem. J. 2000, 349, 547-557. [CrossRef]

46. Fang, X.; Yu, S.; Eder, A.; Mao, M.; Bast, R.C., Jr.; Boyd, D.; Mills, G.B. Regulation of BAD phosphorylation at serine 112 by the Ras-mitogen-activated protein kinase pathway. Oncogene 1999, 18, 6635-6640. [CrossRef]

47. Datta, S.R.; Dudek, H.; Tao, X.; Masters, S.; Fu, H.; Gotoh, Y.; Greenberg, M.E. Akt phosphorylation of BAD couples survival signals to the cell-intrinsic death machinery. Cell 1997, 91, 231-241. [CrossRef]

48. Linde, C.I.; Di Leva, F.; Domi, T.; Tosatto, S.C.; Brini, M.; Carafoli, E. Inhibitory interaction of the 14-3-3 proteins with ubiquitous (PMCA1) and tissue-specific (PMCA3) isoforms of the plasma membrane $\mathrm{Ca}^{2+}$ pump. Cell Calcium 2008, 43, 550-561. [CrossRef]

49. Baughman, J.M.; Perocchi, F.; Girgis, H.S.; Plovanich, M.; Belcher-Timme, C.A.; Sancak, Y.; Bao, X.R.; Strittmatter, L.; Goldberger, O.; Bogorad, R.L.; et al. Integrative genomics identifies MCU as an essential component of the mitochondrial calcium uniporter. Nature 2011, 476, 341-345. [CrossRef]

50. De Stefani, D.; Raffaello, A.; Teardo, E.; Szabo, I.; Rizzuto, R. A forty-kilodalton protein of the inner membrane is the mitochondrial calcium uniporter. Nature 2011, 476, 336-340. [CrossRef]

51. McCormack, J.G.; Denton, R.M. The role of intramitochondrial $\mathrm{Ca}^{2+}$ in the regulation of oxidative phosphorylation in mammalian tissues. Biochem. Soc. Trans. 1993, 21, 793-799. [CrossRef] [PubMed]

52. Rizzuto, R.; Marchi, S.; Bonora, M.; Aguiari, P.; Bononi, A.; De Stefani, D.; Giorgi, C.; Leo, S.; Rimessi, A.; Siviero, R.; et al. $\mathrm{Ca}^{2+}$ transfer from the ER to mitochondria: When, how and why. Biochim. Biophys. Acta 2009, 1787, 1342-1351. [CrossRef] [PubMed]

53. Saotome, M.; Safiulina, D.; Szabadkai, G.; Das, S.; Fransson, A.; Aspenstrom, P.; Rizzuto, R.; Hajnoczky, G. Bidirectional $\mathrm{Ca}^{2+}$-dependent control of mitochondrial dynamics by the Miro GTPase. Proc. Natl. Acad. Sci. USA 2008, 105, 20728-20733. [CrossRef] [PubMed]

54. Yi, M.; Weaver, D.; Hajnoczky, G. Control of mitochondrial motility and distribution by the calcium signal: A homeostatic circuit. J. Cell Biol. 2004, 167, 661-672. [CrossRef] [PubMed]

55. Ott, M.; Gogvadze, V.; Orrenius, S.; Zhivotovsky, B. Mitochondria, oxidative stress and cell death. Apoptosis 2007, 12, 913-922. [CrossRef] [PubMed]

56. Marchi, S.; Lupini, L.; Patergnani, S.; Rimessi, A.; Missiroli, S.; Bonora, M.; Bononi, A.; Corra, F.; Giorgi, C.; De Marchi, E.; et al. Downregulation of the mitochondrial calcium uniporter by cancer-related miR-25. Curr. Biol. 2013, 23, 58-63. [CrossRef]

57. Martin, D.; Salinas, M.; Fujita, N.; Tsuruo, T.; Cuadrado, A. Ceramide and reactive oxygen species generated by $\mathrm{H} 2 \mathrm{O} 2$ induce caspase-3-independent degradation of Akt/protein kinase B. J. Biol. Chem. 2002, 277, 42943-42952. [CrossRef]

58. Leslie, N.R.; Bennett, D.; Lindsay, Y.E.; Stewart, H.; Gray, A.; Downes, C.P. Redox regulation of PI 3-kinase signalling via inactivation of PTEN. EMBO J. 2003, 22, 5501-5510. [CrossRef]

59. Hong, J.H.; Moon, S.J.; Byun, H.M.; Kim, M.S.; Jo, H.; Bae, Y.S.; Lee, S.I.; Bootman, M.D.; Roderick, H.L.; Shin, D.M.; et al. Critical role of phospholipase Cgamma1 in the generation of $\mathrm{H} 2 \mathrm{O} 2$-evoked $\left[\mathrm{Ca}^{2+}\right] \mathrm{i}$ oscillations in cultured rat cortical astrocytes. J. Biol. Chem. 2006, 281, 13057-13067. [CrossRef] 
60. Madesh, M.; Hawkins, B.J.; Milovanova, T.; Bhanumathy, C.D.; Joseph, S.K.; Ramachandrarao, S.P.; Sharma, K.; Kurosaki, T.; Fisher, A.B. Selective role for superoxide in InsP3 receptor-mediated mitochondrial dysfunction and endothelial apoptosis. J. Cell Biol. 2005, 170, 1079-1090. [CrossRef]

61. Aarts, M.; Iihara, K.; Wei, W.L.; Xiong, Z.G.; Arundine, M.; Cerwinski, W.; MacDonald, J.F.; Tymianski, M. A key role for TRPM7 channels in anoxic neuronal death. Cell 2003, 115, 863-877. [CrossRef]

62. Crompton, M. The mitochondrial permeability transition pore and its role in cell death. Biochem. J. 1999, 341, 233-249. [CrossRef] [PubMed]

63. Shimizu, S.; Ide, T.; Yanagida, T.; Tsujimoto, Y. Electrophysiological study of a novel large pore formed by Bax and the voltage-dependent anion channel that is permeable to cytochrome c. J. Biol. Chem. 2000, 275, 12321-12325. [CrossRef] [PubMed]

64. Shimizu, S.; Narita, M.; Tsujimoto, Y. Bcl-2 family proteins regulate the release of apoptogenic cytochrome c by the mitochondrial channel VDAC. Nature 1999, 399, 483-487. [CrossRef]

65. Baines, C.P.; Kaiser, R.A.; Sheiko, T.; Craigen, W.J.; Molkentin, J.D. Voltage-dependent anion channels are dispensable for mitochondrial-dependent cell death. Nat. Cell Biol. 2007, 9, 550-555. [CrossRef]

66. Baines, C.P.; Kaiser, R.A.; Purcell, N.H.; Blair, N.S.; Osinska, H.; Hambleton, M.A.; Brunskill, E.W.; Sayen, M.R.; Gottlieb, R.A.; Dorn, G.W.; et al. Loss of cyclophilin D reveals a critical role for mitochondrial permeability transition in cell death. Nature 2005, 434, 658-662. [CrossRef]

67. Nakagawa, T.; Shimizu, S.; Watanabe, T.; Yamaguchi, O.; Otsu, K.; Yamagata, H.; Inohara, H.; Kubo, T.; Tsujimoto, Y. Cyclophilin D-dependent mitochondrial permeability transition regulates some necrotic but not apoptotic cell death. Nature 2005, 434, 652-658. [CrossRef]

68. Gogvadze, V.; Robertson, J.D.; Zhivotovsky, B.; Orrenius, S. Cytochrome c release occurs via Ca ${ }^{2+}$-dependent and $\mathrm{Ca}^{2+}$-independent mechanisms that are regulated by Bax. J. Biol. Chem. 2001, 276, 19066-19071. [CrossRef]

69. Marzo, I.; Brenner, C.; Zamzami, N.; Jurgensmeier, J.M.; Susin, S.A.; Vieira, H.L.; Prevost, M.C.; Xie, Z.; Matsuyama, S.; Reed, J.C.; et al. Bax and adenine nucleotide translocator cooperate in the mitochondrial control of apoptosis. Science 1998, 281, 2027-2031. [CrossRef]

70. Kaufman, R.J. Orchestrating the unfolded protein response in health and disease. J. Clin. Investig. 2002, 110, 1389-1398. [CrossRef]

71. Nakagawa, T.; Zhu, H.; Morishima, N.; Li, E.; Xu, J.; Yankner, B.A.; Yuan, J. Caspase-12 mediates endoplasmic-reticulum-specific apoptosis and cytotoxicity by amyloid-beta. Nature 2000, 403, 98-103. [CrossRef] [PubMed]

72. Storr, S.J.; Carragher, N.O.; Frame, M.C.; Parr, T.; Martin, S.G. The calpain system and cancer. Nat. Rev. Cancer 2011, 11, 364-374. [CrossRef] [PubMed]

73. Nakagawa, T.; Yuan, J. Cross-talk between two cysteine protease families. Activation of caspase-12 by calpain in apoptosis. J. Cell Biol. 2000, 150, 887-894. [CrossRef] [PubMed]

74. Gil-Parrado, S.; Fernandez-Montalvan, A.; Assfalg-Machleidt, I.; Popp, O.; Bestvater, F.; Holloschi, A.; Knoch, T.A.; Auerswald, E.A.; Welsh, K.; Reed, J.C.; et al. Ionomycin-activated calpain triggers apoptosis. A probable role for Bcl-2 family members. J. Biol. Chem. 2002, 277, 27217-27226. [CrossRef]

75. Bano, D.; Young, K.W.; Guerin, C.J.; Lefeuvre, R.; Rothwell, N.J.; Naldini, L.; Rizzuto, R.; Carafoli, E.; Nicotera, P. Cleavage of the plasma membrane $\mathrm{Na}+/ \mathrm{Ca}^{2+}$ exchanger in excitotoxicity. Cell 2005, 120, 275-285. [CrossRef]

76. Paszty, K.; Antalffy, G.; Hegedus, L.; Padanyi, R.; Penheiter, A.R.; Filoteo, A.G.; Penniston, J.T.; Enyedi, A. Cleavage of the plasma membrane Ca+ATPase during apoptosis. Ann. N. Y. Acad. Sci. 2007, 1099, 440-450. [CrossRef]

77. Paszty, K.; Antalffy, G.; Penheiter, A.R.; Homolya, L.; Padanyi, R.; Ilias, A.; Filoteo, A.G.; Penniston, J.T.; Enyedi, A. The caspase- 3 cleavage product of the plasma membrane $\mathrm{Ca}^{2+}$-ATPase $4 \mathrm{~b}$ is activated and appropriately targeted. Biochem. J. 2005, 391, 687-692. [CrossRef]

78. Paszty, K.; Verma, A.K.; Padanyi, R.; Filoteo, A.G.; Penniston, J.T.; Enyedi, A. Plasma membrane Ca ${ }^{2+}$ ATPase $^{2}$ isoform $4 \mathrm{~b}$ is cleaved and activated by caspase-3 during the early phase of apoptosis. J. Biol. Chem. 2002, 277, 6822-6829. [CrossRef]

79. Schwab, B.L.; Guerini, D.; Didszun, C.; Bano, D.; Ferrando-May, E.; Fava, E.; Tam, J.; Xu, D.; Xanthoudakis, S.; Nicholson, D.W.; et al. Cleavage of plasma membrane calcium pumps by caspases: A link between apoptosis and necrosis. Cell Death Differ. 2002, 9, 818-831. [CrossRef] 
80. Chen, R.; Valencia, I.; Zhong, F.; McColl, K.S.; Roderick, H.L.; Bootman, M.D.; Berridge, M.J.; Conway, S.J.; Holmes, A.B.; Mignery, G.A.; et al. Bcl-2 functionally interacts with inositol 1,4,5-trisphosphate receptors to regulate calcium release from the ER in response to inositol 1,4,5-trisphosphate. J. Cell Biol. 2004, 166, 193-203. [CrossRef]

81. Foyouzi-Youssefi, R.; Arnaudeau, S.; Borner, C.; Kelley, W.L.; Tschopp, J.; Lew, D.P.; Demaurex, N.; Krause, K.H. $\mathrm{Bcl}-2$ decreases the free $\mathrm{Ca}^{2+}$ concentration within the endoplasmic reticulum. Proc. Natl. Acad. Sci. USA 2000, 97, 5723-5728. [CrossRef] [PubMed]

82. Kuo, T.H.; Kim, H.R.; Zhu, L.; Yu, Y.; Lin, H.M.; Tsang, W. Modulation of endoplasmic reticulum calcium pump by Bcl-2. Oncogene 1998, 17, 1903-1910. [CrossRef]

83. Ferdek, P.E.; Gerasimenko, J.V.; Peng, S.; Tepikin, A.V.; Petersen, O.H.; Gerasimenko, O.V. A novel role for Bcl-2 in regulation of cellular calcium extrusion. Curr. Biol. 2012, 22, 1241-1246. [CrossRef] [PubMed]

84. Murphy, A.N.; Bredesen, D.E.; Cortopassi, G.; Wang, E.; Fiskum, G. Bcl-2 potentiates the maximal calcium uptake capacity of neural cell mitochondria. Proc. Natl. Acad. Sci. USA 1996, 93, 9893-9898. [CrossRef] [PubMed]

85. Boehning, D.; Patterson, R.L.; Sedaghat, L.; Glebova, N.O.; Kurosaki, T.; Snyder, S.H. Cytochrome c binds to inositol $(1,4,5)$ trisphosphate receptors, amplifying calcium-dependent apoptosis. Nat. Cell Biol. 2003, 5, 1051-1061. [CrossRef]

86. Oakes, S.A.; Scorrano, L.; Opferman, J.T.; Bassik, M.C.; Nishino, M.; Pozzan, T.; Korsmeyer, S.J. Proapoptotic BAX and BAK regulate the type 1 inositol trisphosphate receptor and calcium leak from the endoplasmic reticulum. Proc. Natl. Acad. Sci. USA 2005, 102, 105-110. [CrossRef]

87. Scorrano, L.; Oakes, S.A.; Opferman, J.T.; Cheng, E.H.; Sorcinelli, M.D.; Pozzan, T.; Korsmeyer, S.J. BAX and BAK regulation of endoplasmic reticulum $\mathrm{Ca}^{2+}$ : A control point for apoptosis. Science 2003, 300, 135-139. [CrossRef]

88. White, C.; Li, C.; Yang, J.; Petrenko, N.B.; Madesh, M.; Thompson, C.B.; Foskett, J.K. The endoplasmic reticulum gateway to apoptosis by Bcl-X(L) modulation of the InsP3R. Nat. Cell Biol. 2005, 7, 1021-1028. [CrossRef]

89. Beck, C.; Robert, I.; Reina-San-Martin, B.; Schreiber, V.; Dantzer, F. Poly(ADP-ribose) polymerases in double-strand break repair: Focus on PARP1, PARP2 and PARP3. Exp. Cell Res. 2014, 329, 18-25. [CrossRef]

90. Kanchanawong, P.; Shtengel, G.; Pasapera, A.M.; Ramko, E.B.; Davidson, M.W.; Hess, H.F.; Waterman, C.M. Nanoscale architecture of integrin-based cell adhesions. Nature 2010, 468, 580-584. [CrossRef]

91. Vicente-Manzanares, M.; Ma, X.; Adelstein, R.S.; Horwitz, A.R. Non-muscle myosin II takes centre stage in cell adhesion and migration. Nat. Rev. Mol. Cell Biol. 2009, 10, 778-790. [CrossRef] [PubMed]

92. Prevarskaya, N.; Skryma, R.; Shuba, Y. Calcium in tumour metastasis: New roles for known actors. Nat. Rev. Cancer 2011, 11, 609-618. [CrossRef] [PubMed]

93. Blaser, H.; Reichman-Fried, M.; Castanon, I.; Dumstrei, K.; Marlow, F.L.; Kawakami, K.; Solnica-Krezel, L.; Heisenberg, C.P.; Raz, E. Migration of zebrafish primordial germ cells: A role for myosin contraction and cytoplasmic flow. Dev. Cell 2006, 11, 613-627. [CrossRef] [PubMed]

94. Hahn, K.; DeBiasio, R.; Taylor, D.L. Patterns of elevated free calcium and calmodulin activation in living cells. Nature 1992, 359, 736-738. [CrossRef]

95. Franco, S.J.; Huttenlocher, A. Regulating cell migration: Calpains make the cut. J. Cell Sci. 2005, 118, 3829-3838. [CrossRef]

96. Wei, C.; Wang, X.; Chen, M.; Ouyang, K.; Song, L.S.; Cheng, H. Calcium flickers steer cell migration. Nature 2009, 457, 901-905. [CrossRef]

97. Tsai, F.C.; Meyer, T. $\mathrm{Ca}^{2+}$ pulses control local cycles of lamellipodia retraction and adhesion along the front of migrating cells. Curr. Biol. 2012, 22, 837-842. [CrossRef]

98. Fan, R.S.; Jacamo, R.O.; Jiang, X.; Sinnett-Smith, J.; Rozengurt, E. G protein-coupled receptor activation rapidly stimulates focal adhesion kinase phosphorylation at Ser-843. Mediation by $\mathrm{Ca}^{2+}$, calmodulin, and $\mathrm{Ca}^{2+} /$ calmodulin-dependent kinase II. J. Biol. Chem. 2005, 280, 24212-24220. [CrossRef]

99. Taniyama, Y.; Weber, D.S.; Rocic, P.; Hilenski, L.; Akers, M.L.; Park, J.; Hemmings, B.A.; Alexander, R.W.; Griendling, K.K. Pyk2- and Src-dependent tyrosine phosphorylation of PDK1 regulates focal adhesions. Mol. Cell Biol. 2003, 23, 8019-8029. [CrossRef]

100. Wan, T.C.; Zabe, M.; Dean, W.L. Plasma membrane $\mathrm{Ca}^{2+}$-ATPase isoform $4 \mathrm{~b}$ is phosphorylated on tyrosine 1176 in activated human platelets. Thromb. Haemost. 2003, 89, 122-131. [CrossRef]

101. Yoon, S.O.; Park, S.J.; Yun, C.H.; Chung, A.S. Roles of matrix metalloproteinases in tumor metastasis and angiogenesis. J. Biochem. Mol. Biol. 2003, 36, 128-137. [CrossRef] [PubMed] 
102. Mueller, A.; Bachi, T.; Hochli, M.; Schafer, B.W.; Heizmann, C.W. Subcellular distribution of S100 proteins in tumor cells and their relocation in response to calcium activation. Histochem. Cell Biol. 1999, 111, 453-459. [CrossRef] [PubMed]

103. Boye, K.; Maelandsmo, G.M. S100A4 and metastasis: A small actor playing many roles. Am. J. Pathol. 2010, 176, 528-535. [CrossRef] [PubMed]

104. Saleem, M.; Kweon, M.H.; Johnson, J.J.; Adhami, V.M.; Elcheva, I.; Khan, N.; Bin Hafeez, B.; Bhat, K.M.; Sarfaraz, S.; Reagan-Shaw, S.; et al. S100A4 accelerates tumorigenesis and invasion of human prostate cancer through the transcriptional regulation of matrix metalloproteinase 9. Proc. Natl. Acad. Sci. USA 2006, 103, 14825-14830. [CrossRef]

105. Coste, B.; Mathur, J.; Schmidt, M.; Earley, T.J.; Ranade, S.; Petrus, M.J.; Dubin, A.E.; Patapoutian, A. Piezo1 and Piezo2 are essential components of distinct mechanically activated cation channels. Science 2010, 330, 55-60. [CrossRef]

106. De Felice, D.; Alaimo, A. Mechanosensitive Piezo Channels in Cancer: Focus on altered Calcium Signaling in Cancer Cells and in Tumor Progression. Cancers 2020, 12, 1780. [CrossRef]

107. Honore, E.; Martins, J.R.; Penton, D.; Patel, A.; Demolombe, S. The Piezo Mechanosensitive Ion Channels: May the Force Be with You! Rev. Physiol. Biochem. Pharmacol. 2015, 169, 25-41. [CrossRef]

108. Ridone, P.; Vassalli, M.; Martinac, B. Piezo1 mechanosensitive channels: What are they and why are they important. Biophys. Rev. 2019, 11, 795-805. [CrossRef]

109. Ryazanova, L.V.; Dorovkov, M.V.; Ansari, A.; Ryazanov, A.G. Characterization of the protein kinase activity of TRPM7/ChaK1, a protein kinase fused to the transient receptor potential ion channel. J. Biol. Chem. 2004, 279, 3708-3716. [CrossRef]

110. Runnels, L.W.; Yue, L.; Clapham, D.E. TRP-PLIK, a bifunctional protein with kinase and ion channel activities. Science 2001, 291, 1043-1047. [CrossRef]

111. Pottosin, I.; Delgado-Enciso, I.; Bonales-Alatorre, E.; Nieto-Pescador, M.G.; Moreno-Galindo, E.G.; Dobrovinskaya, O. Mechanosensitive $\mathrm{Ca}^{2+}$-permeable channels in human leukemic cells: Pharmacological and molecular evidence for TRPV2. Biochim. Biophys. Acta 2015, 1848, 51-59. [CrossRef] [PubMed]

112. Hope, J.M.; Greenlee, J.D.; King, M.R. Mechanosensitive Ion Channels: TRPV4 and P2X7 in Disseminating Cancer Cells. Cancer J. 2018, 24, 84-92. [CrossRef] [PubMed]

113. Petho, Z.; Najder, K.; Bulk, E.; Schwab, A. Mechanosensitive ion channels push cancer progression. Cell Calcium 2019, 80, 79-90. [CrossRef] [PubMed]

114. Gargalionis, A.N.; Basdra, E.K.; Papavassiliou, A.G. Polycystins in Colorectal Cancer. Int. J. Mol. Sci. 2018, 20, 104. [CrossRef]

115. Hanahan, D.; Weinberg, R.A. The hallmarks of cancer. Cell 2000, 100, 57-70. [CrossRef]

116. Wei, C.; Wang, X.; Chen, M.; Ouyang, K.; Zheng, M.; Cheng, H. Flickering calcium microdomains signal turning of migrating cells. Can. J. Physiol. Pharmacol. 2010, 88, 105-110. [CrossRef]

117. Su, L.T.; Agapito, M.A.; Li, M.; Simonson, W.T.; Huttenlocher, A.; Habas, R.; Yue, L.; Runnels, L.W. TRPM7 regulates cell adhesion by controlling the calcium-dependent protease calpain. J. Biol. Chem. 2006, 281, 11260-11270. [CrossRef]

118. Clark, K.; Langeslag, M.; van Leeuwen, B.; Ran, L.; Ryazanov, A.G.; Figdor, C.G.; Moolenaar, W.H.; Jalink, K.; van Leeuwen, F.N. TRPM7, a novel regulator of actomyosin contractility and cell adhesion. EMBO J. 2006, 25, 290-301. [CrossRef]

119. Ellis, L.M.; Hicklin, D.J. VEGF-targeted therapy: Mechanisms of anti-tumour activity. Nat. Rev. Cancer 2008, 8, 579-591. [CrossRef]

120. Li, J.; Cubbon, R.M.; Wilson, L.A.; Amer, M.S.; McKeown, L.; Hou, B.; Majeed, Y.; Tumova, S.; Seymour, V.A.; Taylor, H.; et al. Orai1 and CRAC channel dependence of VEGF-activated $\mathrm{Ca}^{2+}$ entry and endothelial tube formation. Circ. Res. 2011, 108, 1190-1198. [CrossRef]

121. Hou, M.F.; Kuo, H.C.; Li, J.H.; Wang, Y.S.; Chang, C.C.; Chen, K.C.; Chen, W.C.; Chiu, C.C.; Yang, S.; Chang, W.C. Orai1/CRACM1 overexpression suppresses cell proliferation via attenuation of the store-operated calcium influx-mediated signalling pathway in A549 lung cancer cells. Biochim. Biophys. Acta 2011, 1810, 1278-1284. [CrossRef] [PubMed]

122. McAndrew, D.; Grice, D.M.; Peters, A.A.; Davis, F.M.; Stewart, T.; Rice, M.; Smart, C.E.; Brown, M.A.; Kenny, P.A.; Roberts-Thomson, S.J.; et al. ORAI1-mediated calcium influx in lactation and in breast cancer. Mol. Cancer Ther. 2011, 10, 448-460. [CrossRef] [PubMed] 
123. Motiani, R.K.; Abdullaev, I.F.; Trebak, M. A novel native store-operated calcium channel encoded by Orai3: Selective requirement of Orai3 versus Orai1 in estrogen receptor-positive versus estrogen receptor-negative breast cancer cells. J. Biol. Chem. 2010, 285, 19173-19183. [CrossRef]

124. Kim, J.H.; Lkhagvadorj, S.; Lee, M.R.; Hwang, K.H.; Chung, H.C.; Jung, J.H.; Cha, S.K.; Eom, M. Orai1 and STIM1 are critical for cell migration and proliferation of clear cell renal cell carcinoma. Biochem. Biophys. Res. Commun. 2014, 448, 76-82. [CrossRef] [PubMed]

125. Moccia, F.; Dragoni, S.; Poletto, V.; Rosti, V.; Tanzi, F.; Ganini, C.; Porta, C. Orai1 and transient receptor potential channels as novel molecular targets to impair tumor neovascularization in renal cell carcinoma and other malignancies. AntiCancer Agents Med. Chem. 2014, 14, 296-312. [CrossRef] [PubMed]

126. Dubois, C.; Vanden Abeele, F.; Lehen'kyi, V.; Gkika, D.; Guarmit, B.; Lepage, G.; Slomianny, C.; Borowiec, A.S.; Bidaux, G.; Benahmed, M.; et al. Remodeling of Channel-Forming ORAI Proteins Determines an Oncogenic Switch in Prostate Cancer. Cancer Cell 2014. [CrossRef]

127. Flourakis, M.; Lehen'kyi, V.; Beck, B.; Raphael, M.; Vandenberghe, M.; Abeele, F.V.; Roudbaraki, M.; Lepage, G.; Mauroy, B.; Romanin, C.; et al. Orai1 contributes to the establishment of an apoptosis-resistant phenotype in prostate cancer cells. Cell Death Dis. 2010, 1, e75. [CrossRef]

128. Zhu, H.; Zhang, H.; Jin, F.; Fang, M.; Huang, M.; Yang, C.S.; Chen, T.; Fu, L.; Pan, Z. Elevated Orai1 expression mediates tumor-promoting intracellular $\mathrm{Ca}^{2+}$ oscillations in human esophageal squamous cell carcinoma. Oncotarget 2014, 5, 3455-3471. [CrossRef]

129. Faouzi, M.; Hague, F.; Potier, M.; Ahidouch, A.; Sevestre, H.; Ouadid-Ahidouch, H. Down-regulation of Orai3 arrests cell-cycle progression and induces apoptosis in breast cancer cells but not in normal breast epithelial cells. J. Cell Physiol. 2011, 226, 542-551. [CrossRef]

130. Faouzi, M.; Kischel, P.; Hague, F.; Ahidouch, A.; Benzerdjeb, N.; Sevestre, H.; Penner, R.; Ouadid-Ahidouch, H. ORAI3 silencing alters cell proliferation and cell cycle progression via c-myc pathway in breast cancer cells. Biochim. Biophys. Acta 2013, 1833, 752-760. [CrossRef]

131. Motiani, R.K.; Zhang, X.; Harmon, K.E.; Keller, R.S.; Matrougui, K.; Bennett, J.A.; Trebak, M. Orai3 is an estrogen receptor alpha-regulated $\mathrm{Ca}^{2+}$ channel that promotes tumorigenesis. FASEB J. 2013, 27, 63-75. [CrossRef]

132. Holzmann, C.; Kilch, T.; Kappel, S.; Armbruster, A.; Jung, V.; Stockle, M.; Bogeski, I.; Schwarz, E.C.; Peinelt, C. ICRAC controls the rapid androgen response in human primary prostate epithelial cells and is altered in prostate cancer. Oncotarget 2013, 4, 2096-2107. [CrossRef] [PubMed]

133. Ay, A.S.; Benzerdjerb, N.; Sevestre, H.; Ahidouch, A.; Ouadid-Ahidouch, H. Orai3 constitutes a native store-operated calcium entry that regulates non small cell lung adenocarcinoma cell proliferation. PLoS ONE 2013, 8, e72889. [CrossRef] [PubMed]

134. Chen, Y.F.; Chiu, W.T.; Chen, Y.T.; Lin, P.Y.; Huang, H.J.; Chou, C.Y.; Chang, H.C.; Tang, M.J.; Shen, M.R. Calcium store sensor stromal-interaction molecule 1-dependent signaling plays an important role in cervical cancer growth, migration, and angiogenesis. Proc. Natl. Acad. Sci. USA 2011, 108, 15225-15230. [CrossRef] [PubMed]

135. Yang, S.; Zhang, J.J.; Huang, X.Y. Orai1 and STIM1 are critical for breast tumor cell migration and metastasis. Cancer Cell 2009, 15, 124-134. [CrossRef] [PubMed]

136. Dhennin-Duthille, I.; Gautier, M.; Faouzi, M.; Guilbert, A.; Brevet, M.; Vaudry, D.; Ahidouch, A.; Sevestre, H.; Ouadid-Ahidouch, H. High expression of transient receptor potential channels in human breast cancer epithelial cells and tissues: Correlation with pathological parameters. Cell. Physiol. Biochem. 2011, 28, 813-822. [CrossRef] [PubMed]

137. Aydar, E.; Yeo, S.; Djamgoz, M.; Palmer, C. Abnormal expression, localization and interaction of canonical transient receptor potential ion channels in human breast cancer cell lines and tissues: A potential target for breast cancer diagnosis and therapy. Cancer Cell Int. 2009, 9, 23. [CrossRef]

138. Yang, S.L.; Cao, Q.; Zhou, K.C.; Feng, Y.J.; Wang, Y.Z. Transient receptor potential channel C3 contributes to the progression of human ovarian cancer. Oncogene 2009, 28, 1320-1328. [CrossRef]

139. Ding, X.; He, Z.; Zhou, K.; Cheng, J.; Yao, H.; Lu, D.; Cai, R.; Jin, Y.; Dong, B.; Xu, Y.; et al. Essential role of TRPC6 channels in G2/M phase transition and development of human glioma. J. Natl. Cancer Inst. 2010, 102, 1052-1068. [CrossRef]

140. El Boustany, C.; Bidaux, G.; Enfissi, A.; Delcourt, P.; Prevarskaya, N.; Capiod, T. Capacitative calcium entry and transient receptor potential canonical 6 expression control human hepatoma cell proliferation. Hepatology 2008, 47, 2068-2077. [CrossRef] 
141. Shi, Y.; Ding, X.; He, Z.H.; Zhou, K.C.; Wang, Q.; Wang, Y.Z. Critical role of TRPC6 channels in G2 phase transition and the development of human oesophageal cancer. Gut 2009, 58, 1443-1450. [CrossRef] [PubMed]

142. Rybarczyk, P.; Gautier, M.; Hague, F.; Dhennin-Duthille, I.; Chatelain, D.; Kerr-Conte, J.; Pattou, F.; Regimbeau, J.M.; Sevestre, H.; Ouadid-Ahidouch, H. Transient receptor potential melastatin-related 7 channel is overexpressed in human pancreatic ductal adenocarcinomas and regulates human pancreatic cancer cell migration. Int. J. Cancer 2012, 131, E851-E861. [CrossRef] [PubMed]

143. Chen, J.P.; Luan, Y.; You, C.X.; Chen, X.H.; Luo, R.C.; Li, R. TRPM7 regulates the migration of human nasopharyngeal carcinoma cell by mediating $\mathrm{Ca}^{2+}$ influx. Cell Calcium 2010, 47, 425-432. [CrossRef] [PubMed]

144. Yee, N.S.; Zhou, W.; Lee, M. Transient receptor potential channel TRPM8 is over-expressed and required for cellular proliferation in pancreatic adenocarcinoma. Cancer Lett. 2010, 297, 49-55. [CrossRef]

145. Schmidt, U.; Fuessel, S.; Koch, R.; Baretton, G.B.; Lohse, A.; Tomasetti, S.; Unversucht, S.; Froehner, M.; Wirth, M.P.; Meye, A. Quantitative multi-gene expression profiling of primary prostate cancer. Prostate 2006, 66, 1521-1534. [CrossRef]

146. Tsavaler, L.; Shapero, M.H.; Morkowski, S.; Laus, R. Trp-p8, a novel prostate-specific gene, is up-regulated in prostate cancer and other malignancies and shares high homology with transient receptor potential calcium channel proteins. Cancer Res. 2001, 61, 3760-3769.

147. Wondergem, R.; Bartley, J.W. Menthol increases human glioblastoma intracellular $\mathrm{Ca}^{2+}$, $\mathrm{BK}$ channel activity and cell migration. J. Biomed. Sci. 2009, 16, 90. [CrossRef]

148. Wondergem, R.; Ecay, T.W.; Mahieu, F.; Owsianik, G.; Nilius, B. HGF/SF and menthol increase human glioblastoma cell calcium and migration. Biochem. Biophys. Res. Commun. 2008, 372, 210-215. [CrossRef]

149. Waning, J.; Vriens, J.; Owsianik, G.; Stuwe, L.; Mally, S.; Fabian, A.; Frippiat, C.; Nilius, B.; Schwab, A. A novel function of capsaicin-sensitive TRPV1 channels: Involvement in cell migration. Cell Calcium 2007, 42, 17-25. [CrossRef]

150. Kalogris, C.; Caprodossi, S.; Amantini, C.; Lambertucci, F.; Nabissi, M.; Morelli, M.B.; Farfariello, V.; Filosa, A.; Emiliozzi, M.C.; Mammana, G.; et al. Expression of transient receptor potential vanilloid-1 (TRPV1) in urothelial cancers of human bladder: Relation to clinicopathological and molecular parameters. Histopathology 2010, 57, 744-752. [CrossRef]

151. Czifra, G.; Varga, A.; Nyeste, K.; Marincsak, R.; Toth, B.I.; Kovacs, I.; Kovacs, L.; Biro, T. Increased expressions of cannabinoid receptor-1 and transient receptor potential vanilloid-1 in human prostate carcinoma. J. Cancer Res. Clin. Oncol. 2009, 135, 507-514. [CrossRef] [PubMed]

152. Monet, M.; Gkika, D.; Lehen'kyi, V.; Pourtier, A.; Vanden Abeele, F.; Bidaux, G.; Juvin, V.; Rassendren, F.; Humez, S.; Prevarsakaya, N. Lysophospholipids stimulate prostate cancer cell migration via TRPV2 channel activation. Biochim. Biophys. Acta 2009, 1793, 528-539. [CrossRef] [PubMed]

153. Monet, M.; Lehen'kyi, V.; Gackiere, F.; Firlej, V.; Vandenberghe, M.; Roudbaraki, M.; Gkika, D.; Pourtier, A.; Bidaux, G.; Slomianny, C.; et al. Role of cationic channel TRPV2 in promoting prostate cancer migration and progression to androgen resistance. Cancer Res. 2010, 70, 1225-1235. [CrossRef] [PubMed]

154. Bolanz, K.A.; Hediger, M.A.; Landowski, C.P. The role of TRPV6 in breast carcinogenesis. Mol. Cancer Ther. 2008, 7, 271-279. [CrossRef] [PubMed]

155. Fixemer, T.; Wissenbach, U.; Flockerzi, V.; Bonkhoff, H. Expression of the $\mathrm{Ca}^{2+}$-selective cation channel TRPV6 in human prostate cancer: A novel prognostic marker for tumor progression. Oncogene 2003, 22, 7858-7861. [CrossRef] [PubMed]

156. Zhuang, L.; Peng, J.B.; Tou, L.; Takanaga, H.; Adam, R.M.; Hediger, M.A.; Freeman, M.R. Calcium-selective ion channel, CaT1, is apically localized in gastrointestinal tract epithelia and is aberrantly expressed in human malignancies. Lab. Investig. 2002, 82, 1755-1764. [CrossRef]

157. Lee, W.J.; Roberts-Thomson, S.J.; Monteith, G.R. Plasma membrane calcium-ATPase 2 and 4 in human breast cancer cell lines. Biochem. Biophys. Res. Commun. 2005, 337, 779-783. [CrossRef]

158. VanHouten, J.; Sullivan, C.; Bazinet, C.; Ryoo, T.; Camp, R.; Rimm, D.L.; Chung, G.; Wysolmerski, J. PMCA2 regulates apoptosis during mammary gland involution and predicts outcome in breast cancer. Proc. Natl. Acad. Sci. USA 2010, 107, 11405-11410. [CrossRef]

159. Aung, C.S.; Ye, W.; Plowman, G.; Peters, A.A.; Monteith, G.R.; Roberts-Thomson, S.J. Plasma membrane calcium ATPase 4 and the remodeling of calcium homeostasis in human colon cancer cells. Carcinogenesis 2009, 30, 1962-1969. [CrossRef] 
160. Endo, Y.; Uzawa, K.; Mochida, Y.; Shiiba, M.; Bukawa, H.; Yokoe, H.; Tanzawa, H. Sarcoendoplasmic reticulum $\mathrm{Ca}^{2+}$ ATPase type 2 downregulated in human oral squamous cell carcinoma. Int. J. Cancer 2004, 110, 225-231. [CrossRef]

161. Gelebart, P.; Kovacs, T.; Brouland, J.P.; van Gorp, R.; Grossmann, J.; Rivard, N.; Panis, Y.; Martin, V.; Bredoux, R.; Enouf, J.; et al. Expression of endomembrane calcium pumps in colon and gastric cancer cells. Induction of SERCA3 expression during differentiation. J. Biol. Chem. 2002, 277, 26310-26320. [CrossRef] [PubMed]

162. Papp, B.; Brouland, J.P. Altered Endoplasmic Reticulum Calcium Pump Expression during Breast Tumorigenesis. Breast Cancer Basic Clin. Res. 2011, 5, 163-174. [CrossRef] [PubMed]

163. Kang, S.S.; Han, K.S.; Ku, B.M.; Lee, Y.K.; Hong, J.; Shin, H.Y.; Almonte, A.G.; Woo, D.H.; Brat, D.J.; Hwang, E.M.; et al. Caffeine-mediated inhibition of calcium release channel inositol 1,4,5-trisphosphate receptor subtype 3 blocks glioblastoma invasion and extends survival. Cancer Res. 2010, 70, 1173-1183. [CrossRef] [PubMed]

164. Shibao, K.; Fiedler, M.J.; Nagata, J.; Minagawa, N.; Hirata, K.; Nakayama, Y.; Iwakiri, Y.; Nathanson, M.H.; Yamaguchi, $\mathrm{K}$. The type III inositol 1,4,5-trisphosphate receptor is associated with aggressiveness of colorectal carcinoma. Cell Calcium 2010, 48, 315-323. [CrossRef]

165. Wang, J.; Liao, Q.J.; Zhang, Y.; Zhou, H.; Luo, C.H.; Tang, J.; Wang, Y.; Tang, Y.; Zhao, M.; Zhao, X.H.; et al. TRPM7 is required for ovarian cancer cell growth, migration and invasion. Biochem. Biophys. Res. Commun. 2014, 454, 547-553. [CrossRef]

166. Rybarczyk, P.; Vanlaeys, A.; Brassart, B.; Dhennin-Duthille, I.; Chatelain, D.; Sevestre, H.; Ouadid-Ahidouch, H.; Gautier, M. The Transient Receptor Potential Melastatin 7 Channel Regulates Pancreatic Cancer Cell Invasion through the Hsp90alpha/uPA/MMP2 pathway. Neoplasia 2017, 19, 288-300. [CrossRef]

167. Yee, N.S.; Kazi, A.A.; Li, Q.; Yang, Z.; Berg, A.; Yee, R.K. Aberrant over-expression of TRPM7 ion channels in pancreatic cancer: Required for cancer cell invasion and implicated in tumor growth and metastasis. Biol. Open 2015, 4, 507-514. [CrossRef]

168. Gao, S.L.; Kong, C.Z.; Zhang, Z.; Li, Z.L.; Bi, J.B.; Liu, X.K. TRPM7 is overexpressed in bladder cancer and promotes proliferation, migration, invasion and tumor growth. Oncol. Rep. 2017, 38, 1967-1976. [CrossRef]

169. Guilbert, A.; Gautier, M.; Dhennin-Duthille, I.; Rybarczyk, P.; Sahni, J.; Sevestre, H.; Scharenberg, A.M.; Ouadid-Ahidouch, H. Transient receptor potential melastatin 7 is involved in oestrogen receptor-negative metastatic breast cancer cells migration through its kinase domain. Eur. J. Cancer 2013, 49, 3694-3707. [CrossRef]

170. Kuipers, A.J.; Middelbeek, J.; Vrenken, K.; Perez-Gonzalez, C.; Poelmans, G.; Klarenbeek, J.; Jalink, K.; Trepat, X.; van Leeuwen, F.N. TRPM7 controls mesenchymal features of breast cancer cells by tensional regulation of SOX4. Biochim. Biophys. Acta Mol. Basis Dis. 2018, 1864, 2409-2419. [CrossRef]

171. Liu, L.; Wu, N.; Wang, Y.; Zhang, X.; Xia, B.; Tang, J.; Cai, J.; Zhao, Z.; Liao, Q.; Wang, J. TRPM7 promotes the epithelial-mesenchymal transition in ovarian cancer through the calcium-related PI3K / AKT oncogenic signaling. J. Exp. Clin. Cancer Res. 2019, 38, 106. [CrossRef]

172. Cao, R.; Meng, Z.; Liu, T.; Wang, G.; Qian, G.; Cao, T.; Guan, X.; Dan, H.; Xiao, Y.; Wang, X. Decreased TRPM7 inhibits activities and induces apoptosis of bladder cancer cells via ERK1/2 pathway. Oncotarget 2016, 7, 72941-72960. [CrossRef] [PubMed]

173. Sun, Y.; Schaar, A.; Sukumaran, P.; Dhasarathy, A.; Singh, B.B. TGFbeta-induced epithelial-to-mesenchymal transition in prostate cancer cells is mediated via TRPM7 expression. Mol. Carcinog. 2018, 57, 752-761. [CrossRef] [PubMed]

174. Gao, H.; Chen, X.; Du, X.; Guan, B.; Liu, Y.; Zhang, H. EGF enhances the migration of cancer cells by up-regulation of TRPM7. Cell Calcium 2011, 50, 559-568. [CrossRef] [PubMed]

175. Voringer, S.; Schreyer, L.; Nadolni, W.; Meier, M.A.; Woerther, K.; Mittermeier, C.; Ferioli, S.; Singer, S.; Holzer, K.; Zierler, S.; et al. Inhibition of TRPM7 blocks MRTF/SRF-dependent transcriptional and tumorigenic activity. Oncogene 2020, 39, 2328-2344. [CrossRef]

176. Song, C.; Bae, Y.; Jun, J.; Lee, H.; Kim, N.D.; Lee, K.B.; Hur, W.; Park, J.Y.; Sim, T. Identification of TG100-115 as a new and potent TRPM7 kinase inhibitor, which suppresses breast cancer cell migration and invasion. Biochim. Biophys. Acta. Gen. Subj. 2017, 1861, 947-957. [CrossRef] [PubMed]

177. Le, Q.T.; Denko, N.C.; Giaccia, A.J. Hypoxic gene expression and metastasis. Cancer Metastasis Rev. 2004, 23, 293-310. [CrossRef] 
178. Middelbeek, J.; Kuipers, A.J.; Henneman, L.; Visser, D.; Eidhof, I.; van Horssen, R.; Wieringa, B.; Canisius, S.V.; Zwart, W.; Wessels, L.F.; et al. TRPM7 is required for breast tumor cell metastasis. Cancer Res. 2012, 72, 4250-4261. [CrossRef]

179. Faouzi, M.; Kilch, T.; Horgen, F.D.; Fleig, A.; Penner, R. The TRPM7 channel kinase regulates store-operated calcium entry. J. Physiol. 2017, 595, 3165-3180. [CrossRef]

180. Wong, R.; Turlova, E.; Feng, Z.P.; Rutka, J.T.; Sun, H.S. Activation of TRPM7 by naltriben enhances migration and invasion of glioblastoma cells. Oncotarget 2017, 8, 11239-11248. [CrossRef]

181. Chen, H.C.; Su, L.T.; Gonzalez-Pagan, O.; Overton, J.D.; Runnels, L.W. A key role for $\mathrm{Mg}^{2+}$ in TRPM7's control of ROS levels during cell stress. Biochem. J. 2012, 445, 441-448. [CrossRef] [PubMed]

182. Zierler, S.; Yao, G.; Zhang, Z.; Kuo, W.C.; Porzgen, P.; Penner, R.; Horgen, F.D.; Fleig, A. Waixenicin A inhibits cell proliferation through magnesium-dependent block of transient receptor potential melastatin 7 (TRPM7) channels. J. Biol. Chem. 2011, 286, 39328-39335. [CrossRef] [PubMed]

183. Duncan, L.M.; Deeds, J.; Hunter, J.; Shao, J.; Holmgren, L.M.; Woolf, E.A.; Tepper, R.I.; Shyjan, A.W. Down-regulation of the novel gene melastatin correlates with potential for melanoma metastasis. Cancer Res. 1998, 58, 1515-1520. [PubMed]

184. Yang, Z.H.; Wang, X.H.; Wang, H.P.; Hu, L.Q. Effects of TRPM8 on the proliferation and motility of prostate cancer PC-3 cells. Asian J. Androl. 2009, 11, 157-165. [CrossRef] [PubMed]

185. Grolez, G.P.; Gordiendko, D.V.; Clarisse, M.; Hammadi, M.; Desruelles, E.; Fromont, G.; Prevarskaya, N.; Slomianny, C.; Gkika, D. TRPM8-androgen receptor association within lipid rafts promotes prostate cancer cell migration. Cell Death Dis. 2019, 10, 652. [CrossRef]

186. Wang, Y.; Wang, X.; Yang, Z.; Zhu, G.; Chen, D.; Meng, Z. Menthol inhibits the proliferation and motility of prostate cancer DU145 cells. Pathol. Oncol. Res. 2012, 18, 903-910. [CrossRef]

187. Stewart, J.M. TRPV6 as A Target for Cancer Therapy. J. Cancer 2020, 11, 374-387. [CrossRef]

188. Peters, A.A.; Jamaludin, S.Y.N.; Yapa, K.; Chalmers, S.; Wiegmans, A.P.; Lim, H.F.; Milevskiy, M.J.G.; Azimi, I.; Davis, F.M.; Northwood, K.S.; et al. Oncosis and apoptosis induction by activation of an overexpressed ion channel in breast cancer cells. Oncogene 2017, 36, 6490-6500. [CrossRef]

189. Raphael, M.; Lehen'kyi, V.; Vandenberghe, M.; Beck, B.; Khalimonchyk, S.; Vanden Abeele, F.; Farsetti, L.; Germain, E.; Bokhobza, A.; Mihalache, A.; et al. TRPV6 calcium channel translocates to the plasma membrane via Orai1-mediated mechanism and controls cancer cell survival. Proc. Natl. Acad. Sci. USA 2014, 111, E3870-E3879. [CrossRef]

190. Peters, A.A.; Simpson, P.T.; Bassett, J.J.; Lee, J.M.; Da Silva, L.; Reid, L.E.; Song, S.; Parat, M.O.; Lakhani, S.R.; Kenny, P.A.; et al. Calcium channel TRPV6 as a potential therapeutic target in estrogen receptor-negative breast cancer. Mol. Cancer Ther. 2012, 11, 2158-2168. [CrossRef]

191. Song, H.; Dong, M.; Zhou, J.; Sheng, W.; Li, X.; Gao, W. Expression and prognostic significance of TRPV6 in the development and progression of pancreatic cancer. Oncology Rep. 2018, 39, 1432-1440. [CrossRef] [PubMed]

192. Lau, J.K.; Brown, K.C.; Dom, A.M.; Witte, T.R.; Thornhill, B.A.; Crabtree, C.M.; Perry, H.E.; Brown, J.M.; Ball, J.G.; Creel, R.G.; et al. Capsaicin induces apoptosis in human small cell lung cancer via the TRPV6 receptor and the calpain pathway. Apoptosis 2014, 19, 1190-1201. [CrossRef] [PubMed]

193. Xue, H.; Wang, Y.; MacCormack, T.J.; Lutes, T.; Rice, C.; Davey, M.; Dugourd, D.; Ilenchuk, T.T.; Stewart, J.M. Inhibition of Transient Receptor Potential Vanilloid 6 channel, elevated in human ovarian cancers, reduces tumour growth in a xenograft model. J. Cancer 2018, 9, 3196-3207. [CrossRef] [PubMed]

194. Fu, S.; Hirte, H.; Welch, S.; Ilenchuk, T.T.; Lutes, T.; Rice, C.; Fields, N.; Nemet, A.; Dugourd, D.; Piha-Paul, S.; et al. First-in-human phase I study of SOR-C13, a TRPV6 calcium channel inhibitor, in patients with advanced solid tumors. Investig. New Drugs 2017, 35, 324-333. [CrossRef]

195. Fiorio Pla, A.; Ong, H.L.; Cheng, K.T.; Brossa, A.; Bussolati, B.; Lockwich, T.; Paria, B.; Munaron, L.; Ambudkar, I.S. TRPV4 mediates tumor-derived endothelial cell migration via arachidonic acid-activated actin remodeling. Oncogene 2012, 31, 200-212. [CrossRef]

196. Lee, W.H.; Choong, L.Y.; Mon, N.N.; Lu, S.; Lin, Q.; Pang, B.; Yan, B.; Krishna, V.S.; Singh, H.; Tan, T.Z.; et al. TRPV4 Regulates Breast Cancer Cell Extravasation, Stiffness and Actin Cortex. Sci. Rep. 2016, 6, 27903. [CrossRef]

197. Lee, W.H.; Choong, L.Y.; Jin, T.H.; Mon, N.N.; Chong, S.; Liew, C.S.; Putti, T.; Lu, S.Y.; Harteneck, C.; Lim, Y.P. TRPV4 plays a role in breast cancer cell migration via $\mathrm{Ca}^{2+}$-dependent activation of AKT and downregulation of E-cadherin cell cortex protein. Oncogenesis 2017, 6, e338. [CrossRef] 
198. Goyal, N.; Skrdla, P.; Schroyer, R.; Kumar, S.; Fernando, D.; Oughton, A.; Norton, N.; Sprecher, D.L.; Cheriyan, J. Clinical Pharmacokinetics, Safety, and Tolerability of a Novel, First-in-Class TRPV4 Ion Channel Inhibitor, GSK2798745, in Healthy and Heart Failure Subjects. Am. J. Cardiovasc. Drugs 2019, 19, 335-342. [CrossRef]

199. Adapala, R.K.; Thoppil, R.J.; Ghosh, K.; Cappelli, H.C.; Dudley, A.C.; Paruchuri, S.; Keshamouni, V.; Klagsbrun, M.; Meszaros, J.G.; Chilian, W.M.; et al. Activation of mechanosensitive ion channel TRPV4 normalizes tumor vasculature and improves cancer therapy. Oncogene 2016, 35, 314-322. [CrossRef]

200. Almasi, S.; Sterea, A.M.; Fernando, W.; Clements, D.R.; Marcato, P.; Hoskin, D.W.; Gujar, S.; El Hiani, Y. TRPM2 ion channel promotes gastric cancer migration, invasion and tumor growth through the AKT signaling pathway. Sci. Rep. 2019, 9, 4182. [CrossRef]

201. Chen, Z.; Tang, C.; Zhu, Y.; Xie, M.; He, D.; Pan, Q.; Zhang, P.; Hua, D.; Wang, T.; Jin, L.; et al. TrpC5 regulates differentiation through the $\mathrm{Ca}^{2+} / \mathrm{Wnt} 5$ a signalling pathway in colorectal cancer. Clin. Sci. 2017, 131, 227-237. [CrossRef] [PubMed]

202. Chen, Z.; Zhu, Y.; Dong, Y.; Zhang, P.; Han, X.; Jin, J.; Ma, X. Overexpression of TrpC5 promotes tumor metastasis via the HIF-1alpha-Twist signaling pathway in colon cancer. Clin. Sci. 2017, 131, 2439-2450. [CrossRef] [PubMed]

203. Wen, L.; Liang, C.; Chen, E.; Chen, W.; Liang, F.; Zhi, X.; Wei, T.; Xue, F.; Li, G.; Yang, Q.; et al. Regulation of Multi-drug Resistance in hepatocellular carcinoma cells is TRPC6/Calcium Dependent. Sci. Rep. 2016, 6, 23269. [CrossRef] [PubMed]

204. Ding, M.; Wang, H.; Qu, C.; Xu, F.; Zhu, Y.; Lv, G.; Lu, Y.; Zhou, Q.; Zhou, H.; Zeng, X.; et al. Pyrazolo[1,5-a] pyrimidine TRPC6 antagonists for the treatment of gastric cancer. Cancer Lett. 2018, 432, 47-55. [CrossRef]

205. Canales, J.; Morales, D.; Blanco, C.; Rivas, J.; Diaz, N.; Angelopoulos, I.; Cerda, O. A TR(i)P to Cell Migration: New Roles of TRP Channels in Mechanotransduction and Cancer. Front. Physiol. 2019, 10, 757. [CrossRef]

206. Xia, J.; Wang, H.; Huang, H.; Sun, L.; Dong, S.; Huang, N.; Shi, M.; Bin, J.; Liao, Y.; Liao, W. Elevated Orai1 and STIM1 expressions upregulate MACC1 expression to promote tumor cell proliferation, metabolism, migration, and invasion in human gastric cancer. Cancer Lett. 2016, 381, 31-40. [CrossRef]

207. Gueguinou, M.; Crottes, D.; Chantome, A.; Rapetti-Mauss, R.; Potier-Cartereau, M.; Clarysse, L.; Girault, A.; Fourbon, Y.; Jezequel, P.; Guerin-Charbonnel, C.; et al. The SigmaR1 chaperone drives breast and colorectal cancer cell migration by tuning SK3-dependent $\mathrm{Ca}^{2+}$ homeostasis. Oncogene 2017, 36, 3640-3647. [CrossRef]

208. Zhang, Z.; Liu, X.; Feng, B.; Liu, N.; Wu, Q.; Han, Y.; Nie, Y.; Wu, K.; Shi, Y.; Fan, D. STIM1, a direct target of microRNA-185, promotes tumor metastasis and is associated with poor prognosis in colorectal cancer. Oncogene 2015, 34, 4808-4820. [CrossRef]

209. Umemura, M.; Baljinnyam, E.; Feske, S.; De Lorenzo, M.S.; Xie, L.H.; Feng, X.; Oda, K.; Makino, A.; Fujita, T.; Yokoyama, U.; et al. Store-Operated Ca(2) (+) Entry (SOCE) Regulates Melanoma Proliferation and Cell Migration. PLoS ONE 2014, 9, e89292. [CrossRef]

210. Xu, Y.; Zhang, S.; Niu, H.; Ye, Y.; Hu, F.; Chen, S.; Li, X.; Luo, X.; Jiang, S.; Liu, Y.; et al. STIM1 accelerates cell senescence in a remodeled microenvironment but enhances the epithelial-to-mesenchymal transition in prostate cancer. Sci. Rep. 2015, 5, 11754. [CrossRef]

211. Yang, N.; Tang, Y.; Wang, F.; Zhang, H.; Xu, D.; Shen, Y.; Sun, S.; Yang, G. Blockade of store-operated $\mathrm{Ca}^{2+}$ entry inhibits hepatocarcinoma cell migration and invasion by regulating focal adhesion turnover. Cancer Lett. 2013, 330, 163-169. [CrossRef] [PubMed]

212. Frischauf, I.; Litvinukova, M.; Schober, R.; Zayats, V.; Svobodova, B.; Bonhenry, D.; Lunz, V.; Cappello, S.; Tociu, L.; Reha, D.; et al. Transmembrane helix connectivity in Orai1 controls two gates for calcium-dependent transcription. Sci. Signal. 2017, 10. [CrossRef] [PubMed]

213. Gueguinou, M.; Harnois, T.; Crottes, D.; Uguen, A.; Deliot, N.; Gambade, A.; Chantome, A.; Haelters, J.P.; Jaffres, P.A.; Jourdan, M.L.; et al. SK3/TRPC1/Orai1 complex regulates SOCE-dependent colon cancer cell migration: A novel opportunity to modulate anti-EGFR mAb action by the alkyl-lipid Ohmline. Oncotarget 2016, 7, 36168-36184. [CrossRef] [PubMed]

214. Badaoui, M.; Mimsy-Julienne, C.; Saby, C.; Van Gulick, L.; Peretti, M.; Jeannesson, P.; Morjani, H.; Ouadid-Ahidouch, H. Collagen type 1 promotes survival of human breast cancer cells by overexpressing Kv10.1 potassium and Orai1 calcium channels through DDR1-dependent pathway. Oncotarget 2018, 9, 24653-24671. [CrossRef] 
215. Peretti, M.; Badaoui, M.; Girault, A.; Van Gulick, L.; Mabille, M.P.; Tebbakha, R.; Sevestre, H.; Morjani, H.; Ouadid-Ahidouch, H. Original association of ion transporters mediates the ECM-induced breast cancer cell survival: Kv10.1-Orai1-SPCA2 partnership. Sci. Rep. 2019, 9, 1175. [CrossRef]

216. Wang, J.Y.; Sun, J.; Huang, M.Y.; Wang, Y.S.; Hou, M.F.; Sun, Y.; He, H.; Krishna, N.; Chiu, S.J.; Lin, S.; et al. STIM1 overexpression promotes colorectal cancer progression, cell motility and COX-2 expression. Oncogene 2015, 34, 4358-4367. [CrossRef]

217. Hoth, M.; Niemeyer, B.A. The neglected CRAC proteins: Orai2, Orai3, and STIM2. Curr. Top. Membr. 2013, 71, 237-271. [CrossRef]

218. Soboloff, J.; Rothberg, B.S.; Madesh, M.; Gill, D.L. STIM proteins: Dynamic calcium signal transducers. Nat. Rev. Mol. Cell Biol. 2012, 13, 549-565. [CrossRef]

219. Thompson, J.L.; Mignen, O.; Shuttleworth, T.J. The ARC channel-an endogenous store-independent Orai channel. Curr. Top. Membr. 2013, 71, 125-148. [CrossRef]

220. Mignen, O.; Thompson, J.L.; Shuttleworth, T.J. Both Orai1 and Orai3 are essential components of the arachidonate-regulated $\mathrm{Ca}^{2+}$-selective (ARC) channels. J. Physiol. 2008, 586, 185-195. [CrossRef]

221. Thompson, J.L.; Shuttleworth, T.J. Orai channel-dependent activation of phospholipase C-delta: A novel mechanism for the effects of calcium entry on calcium oscillations. J. Physiol. 2011, 589, 5057-5069. [CrossRef] [PubMed]

222. Goswamee, P.; Pounardjian, T.; Giovannucci, D.R. Arachidonic acid-induced $\mathrm{Ca}^{2+}$ entry and migration in a neuroendocrine cancer cell line. Cancer Cell Int. 2018, 18, 30. [CrossRef] [PubMed]

223. Roos, J.; DiGregorio, P.J.; Yeromin, A.V.; Ohlsen, K.; Lioudyno, M.; Zhang, S.; Safrina, O.; Kozak, J.A.; Wagner, S.L.; Cahalan, M.D.; et al. STIM1, an essential and conserved component of store-operated Ca ${ }^{2+}$ channel function. J. Cell Biol. 2005, 169, 435-445. [CrossRef] [PubMed]

224. Oritani, K.; Kincade, P.W. Identification of stromal cell products that interact with pre-B cells. J. Cell Biol. 1996, 134, 771-782. [CrossRef] [PubMed]

225. Hassan, S.; Carraway, R.E. Involvement of arachidonic acid metabolism and EGF receptor in neurotensin-induced prostate cancer PC3 cell growth. Regul. Pept. 2006, 133, 105-114. [CrossRef]

226. Villegas-Comonfort, S.; Castillo-Sanchez, R.; Serna-Marquez, N.; Cortes-Reynosa, P.; Salazar, E.P. Arachidonic acid promotes migration and invasion through a PI3K/Akt-dependent pathway in MDA-MB-231 breast cancer cells. Prostaglandins Leukot. and Essent. Fat. Acids 2014, 90, 169-177. [CrossRef]

227. Feng, M.; Grice, D.M.; Faddy, H.M.; Nguyen, N.; Leitch, S.; Wang, Y.; Muend, S.; Kenny, P.A.; Sukumar, S.; Roberts-Thomson, S.J.; et al. Store-independent activation of Orai1 by SPCA2 in mammary tumors. Cell 2010, 143, 84-98. [CrossRef]

228. Missiaen, L.; Dode, L.; Vanoevelen, J.; Raeymaekers, L.; Wuytack, F. Calcium in the Golgi apparatus. Cell Calcium 2007, 41, 405-416. [CrossRef]

229. Dang, D.; Prasad, H.; Rao, R. Secretory pathway $\mathrm{Ca}^{2+}$-ATPases promote in vitro microcalcifications in breast cancer cells. Mol. Carcinog. 2017, 56, 2474-2485. [CrossRef]

230. Grice, D.M.; Vetter, I.; Faddy, H.M.; Kenny, P.A.; Roberts-Thomson, S.J.; Monteith, G.R. Golgi calcium pump secretory pathway calcium ATPase 1 (SPCA1) is a key regulator of insulin-like growth factor receptor (IGF1R) processing in the basal-like breast cancer cell line MDA-MB-231. J. Biol. Chem. 2010, 285, 37458-37466. [CrossRef]

231. Curry, M.C.; Luk, N.A.; Kenny, P.A.; Roberts-Thomson, S.J.; Monteith, G.R. Distinct regulation of cytoplasmic calcium signals and cell death pathways by different plasma membrane calcium ATPase isoforms in MDA-MB-231 breast cancer cells. J. Biol. Chem. 2012, 287, 28598-28608. [CrossRef] [PubMed]

232. Sritangos, P.; Pena Alarcon, E.; James, A.D.; Sultan, A.; Richardson, D.A.; Bruce, J.I.E. Plasma Membrane Ca ${ }^{2+}$ ATPase Isoform 4 (PMCA4) Has an Important Role in Numerous Hallmarks of Pancreatic Cancer. Cancers 2020, 12, 218. [CrossRef] [PubMed]

233. Watson, C.J. Involution: Apoptosis and tissue remodelling that convert the mammary gland from milk factory to a quiescent organ. Breast Cancer Res. 2006, 8, 203. [CrossRef] [PubMed]

234. Jeong, J.; VanHouten, J.N.; Dann, P.; Kim, W.; Sullivan, C.; Yu, H.; Liotta, L.; Espina, V.; Stern, D.F.; Friedman, P.A.; et al. PMCA2 regulates HER2 protein kinase localization and signaling and promotes HER2-mediated breast cancer. Proc. Natl. Acad. Sci. USA 2016, 113, E282-E290. [CrossRef] [PubMed]

235. Ward, P.S.; Thompson, C.B. Metabolic reprogramming: A cancer hallmark even warburg did not anticipate. Cancer Cell 2012, 21, 297-308. [CrossRef] [PubMed]

236. Kroemer, G.; Pouyssegur, J. Tumor cell metabolism: Cancer's Achilles' heel. Cancer Cell 2008, 13, 472-482. [CrossRef] 
237. Tosatto, A.; Sommaggio, R.; Kummerow, C.; Bentham, R.B.; Blacker, T.S.; Berecz, T.; Duchen, M.R.; Rosato, A.; Bogeski, I.; Szabadkai, G.; et al. The mitochondrial calcium uniporter regulates breast cancer progression via HIF-1alpha. EMBO Mol. Med. 2016, 8, 569-585. [CrossRef]

238. Vander Heiden, M.G. Targeting cancer metabolism: A therapeutic window opens. Nat. Rev. Drug Discov. 2011, 10, 671-684. [CrossRef]

239. Tennant, D.A.; Duran, R.V.; Gottlieb, E. Targeting metabolic transformation for cancer therapy. Nat. Rev. Cancer 2010, 10, 267-277. [CrossRef]

240. Carafoli, E.; Brini, M. Calcium pumps: Structural basis for and mechanism of calcium transmembrane transport. Curr. Opin. Chem. Biol. 2000, 4, 152-161. [CrossRef]

241. Brini, M.; Carafoli, E. Calcium pumps in health and disease. Physiol. Rev. 2009, 89, 1341-1378. [CrossRef] [PubMed]

242. James, A.; Chan, A.; Erice Azparren, O.; Siriwardena, A.K.; Bruce, J.I.E. Glycolytic ATP fuels the plasma membrane calcium pump critical for pancreatic cancer cell survival. J. Biol. Chem. 2013, 288, 36007-36019. [CrossRef] [PubMed]

243. James, A.D.; Patel, W.; Butt, Z.; Adiamah, M.; Dakhel, R.; Latif, A.; Uggenti, C.; Swanton, E.; Imamura, H.; Siriwardena, A.K.; et al. The Plasma Membrane Calcium Pump in Pancreatic Cancer Cells Exhibiting the Warburg Effect Relies on Glycolytic ATP. J. Biol. Chem. 2015, 290, 24760-24771. [CrossRef] [PubMed]

244. James, A.D.; Richardson, D.A.; Oh, I.W.; Sritangos, P.; Attard, T.; Barrett, L.; Bruce, J.I.E. Cutting off the fuel supply to calcium pumps in pancreatic cancer cells: Role of pyruvate kinase-M2 (PKM2). Br. J. Cancer 2020, 122, 266-278. [CrossRef] [PubMed]

245. Richardson, D.A.; Sritangos, P.; James, A.D.; Sultan, A.; Bruce, J.I.E. Metabolic regulation of calcium pumps in pancreatic cancer: Role of phosphofructokinase-fructose-bisphosphatase-3 (PFKFB3). Cancer Metab. 2020, 8, 2. [CrossRef]

246. Paul, R.J.; Hardin, C.D.; Raeymaekers, L.; Wuytack, F.; Casteels, R. Preferential support of Ca ${ }^{2+}$ uptake in smooth muscle plasma membrane vesicles by an endogenous glycolytic cascade. FASEB J. 1989, 3, 2298-2301. [CrossRef]

247. Hardin, C.D.; Raeymaekers, L.; Paul, R.J. Comparison of endogenous and exogenous sources of ATP in fueling $\mathrm{Ca}^{2+}$ uptake in smooth muscle plasma membrane vesicles. J. Gen. Physiol. 1992, 99, 21-40. [CrossRef]

248. De Bock, K.; Georgiadou, M.; Schoors, S.; Kuchnio, A.; Wong, B.W.; Cantelmo, A.R.; Quaegebeur, A.; Ghesquiere, B.; Cauwenberghs, S.; Eelen, G.; et al. Role of PFKFB3-driven glycolysis in vessel sprouting. Cell 2013, 154, 651-663. [CrossRef]

249. Binnewies, M.; Roberts, E.W.; Kersten, K.; Chan, V.; Fearon, D.F.; Merad, M.; Coussens, L.M.; Gabrilovich, D.I.; Ostrand-Rosenberg, S.; Hedrick, C.C.; et al. Understanding the tumor immune microenvironment (TIME) for effective therapy. Nat. Med. 2018, 24, 541-550. [CrossRef]

250. Gonzalez, H.; Hagerling, C.; Werb, Z. Roles of the immune system in cancer: From tumor initiation to metastatic progression. Genes Dev. 2018, 32, 1267-1284. [CrossRef]

251. Huber, V.; Camisaschi, C.; Berzi, A.; Ferro, S.; Lugini, L.; Triulzi, T.; Tuccitto, A.; Tagliabue, E.; Castelli, C.; Rivoltini, L. Cancer acidity: An ultimate frontier of tumor immune escape and a novel target of immunomodulation. Semin. Cancer Biol. 2017, 43, 74-89. [CrossRef] [PubMed]

252. Clemens, R.A.; Lowell, C.A. CRAC channel regulation of innate immune cells in health and disease. Cell Calcium 2019, 78, 56-65. [CrossRef] [PubMed]

253. Feske, S. ORAI1 and STIM1 deficiency in human and mice: Roles of store-operated $\mathrm{Ca}^{2+}$ entry in the immune system and beyond. Immunol. Rev. 2009, 231, 189-209. [CrossRef] [PubMed]

254. Feske, S. CRAC channels and disease-From human CRAC channelopathies and animal models to novel drugs. Cell Calcium 2019, 80, 112-116. [CrossRef] [PubMed]

255. Feske, S.; Gwack, Y.; Prakriya, M.; Srikanth, S.; Puppel, S.H.; Tanasa, B.; Hogan, P.G.; Lewis, R.S.; Daly, M.; Rao, A. A mutation in Orai1 causes immune deficiency by abrogating CRAC channel function. Nature 2006, 441, 179-185. [CrossRef]

256. Maul-Pavicic, A.; Chiang, S.C.; Rensing-Ehl, A.; Jessen, B.; Fauriat, C.; Wood, S.M.; Sjoqvist, S.; Hufnagel, M.; Schulze, I.; Bass, T.; et al. ORAI1-mediated calcium influx is required for human cytotoxic lymphocyte degranulation and target cell lysis. Proc. Natl. Acad. Sci. USA 2011, 108, 3324-3329. [CrossRef]

257. Schwarz, E.C.; Qu, B.; Hoth, M. Calcium, cancer and killing: The role of calcium in killing cancer cells by cytotoxic T lymphocytes and natural killer cells. Biochim. Biophys. Acta 2013, 1833, 1603-1611. [CrossRef] 
258. Bergmeier, W.; Weidinger, C.; Zee, I.; Feske, S. Emerging roles of store-operated Ca ${ }^{2+}$ entry through STIM and ORAI proteins in immunity, hemostasis and cancer. Channels 2013, 7, 379-391. [CrossRef]

259. Vashisht, A.; Trebak, M.; Motiani, R.K. STIM and Orai proteins as novel targets for cancer therapy. A Review in the Theme: Cell and Molecular Processes in Cancer Metastasis. Am. J. Physiol. Cell Physiol. 2015, 309, C457-C469. [CrossRef]

260. Zhou, X.; Friedmann, K.S.; Lyrmann, H.; Zhou, Y.; Schoppmeyer, R.; Knorck, A.; Mang, S.; Hoxha, C.; Angenendt, A.; Backes, C.S.; et al. A calcium optimum for cytotoxic T lymphocyte and natural killer cell cytotoxicity. J. Physiol. 2018, 596, 2681-2698. [CrossRef]

261. Chenivesse, C.; Tsicopoulos, A. CCL18-Beyond chemotaxis. Cytokine 2018, 109, 52-56. [CrossRef]

262. Chen, J.; Yao, Y.; Gong, C.; Yu, F.; Su, S.; Chen, J.; Liu, B.; Deng, H.; Wang, F.; Lin, L.; et al. CCL18 from tumor-associated macrophages promotes breast cancer metastasis via PITPNM3. Cancer Cell 2011, 19, 541-555. [CrossRef] [PubMed]

263. Yu-Ju Wu, C.; Chen, C.H.; Lin, C.Y.; Feng, L.Y.; Lin, Y.C.; Wei, K.C.; Huang, C.Y.; Fang, J.Y.; Chen, P.Y. CCL5 of glioma-associated microglia/macrophages regulates glioma migration and invasion via calcium-dependent matrix metalloproteinase 2. Neuro-Oncology 2020, 22, 253-266. [CrossRef] [PubMed]

264. Aldinucci, D.; Borghese, C.; Casagrande, N. The CCL5/CCR5 Axis in Cancer Progression. Cancers 2020, 12, 1765. [CrossRef] [PubMed]

265. Ghosh, S.; Adhikary, A.; Chakraborty, S.; Nandi, P.; Mohanty, S.; Chakraborty, S.; Bhattacharjee, P.; Mukherjee, S.; Putatunda, S.; Chakraborty, S.; et al. Nifetepimine, a dihydropyrimidone, ensures CD4+ T cell survival in a tumor microenvironment by maneuvering sarco(endo)plasmic reticulum $\mathrm{Ca}^{2+}$ ATPase (SERCA). J. Biol. Chem. 2012, 287, 32881-32896. [CrossRef] [PubMed]

266. Gatenby, R.A.; Gawlinski, E.T.; Gmitro, A.F.; Kaylor, B.; Gillies, R.J. Acid-mediated tumor invasion: A multidisciplinary study. Cancer Res. 2006, 66, 5216-5223. [CrossRef] [PubMed]

267. Rothberg, J.M.; Bailey, K.M.; Wojtkowiak, J.W.; Ben-Nun, Y.; Bogyo, M.; Weber, E.; Moin, K.; Blum, G.; Mattingly, R.R.; Gillies, R.J.; et al. Acid-mediated tumor proteolysis: Contribution of cysteine cathepsins. Neoplasia 2013, 15, 1125-1137. [CrossRef]

268. Gavriliouk, D.; Scrimgeour, N.R.; Grigoryev, S.; Ma, L.; Zhou, F.H.; Barritt, G.J.; Rychkov, G.Y. Regulation of Orai1/STIM1 mediated ICRAC by intracellular pH. Sci. Rep. 2017, 7, 9829. [CrossRef]

269. Yu, A.S.; Yue, Z.; Feng, J.; Yue, L. Regulation of Orai/STIM Channels by pH. In Calcium Entry Channels in Non-Excitable Cells; Kozak, J.A., Putney, J.W., Jr., Eds.; CRC Press/Taylor \& Francis: Boca Raton, FL, USA, 2018; Chapter 9; pp. 161-176. [CrossRef]

270. Berdiev, B.K.; Xia, J.; McLean, L.A.; Markert, J.M.; Gillespie, G.Y.; Mapstone, T.B.; Naren, A.P.; Jovov, B.; Bubien, J.K.; Ji, H.L.; et al. Acid-sensing ion channels in malignant gliomas. J. Biol. Chem. 2003, 278, 15023-15034. [CrossRef]

271. Jin, C.; Ye, Q.H.; Yuan, F.L.; Gu, Y.L.; Li, J.P.; Shi, Y.H.; Shen, X.M.; Bo, L.; Lin, Z.H. Involvement of acid-sensing ion channel 1alpha in hepatic carcinoma cell migration and invasion. Tumour. Biol. 2015, 36, 4309-4317. [CrossRef]

272. Wu, Y.; Gao, B.; Xiong, Q.J.; Wang, Y.C.; Huang, D.K.; Wu, W.N. Acid-sensing ion channels contribute to the effect of extracellular acidosis on proliferation and migration of A549 cells. Tumour. Biol. 2017, 39. [CrossRef] [PubMed]

273. Zhou, Z.H.; Song, J.W.; Li, W.; Liu, X.; Cao, L.; Wan, L.M.; Tan, Y.X.; Ji, S.P.; Liang, Y.M.; Gong, F. The acid-sensing ion channel, ASIC2, promotes invasion and metastasis of colorectal cancer under acidosis by activating the calcineurin/NFAT1 axis. J. Exp. Clin. Cancer Res. 2017, 36, 130. [CrossRef] [PubMed]

274. Kong, X.; Tang, X.; Du, W.; Tong, J.; Yan, Y.; Zheng, F.; Fang, M.; Gong, F.; Tan, Z. Extracellular acidosis modulates the endocytosis and maturation of macrophages. Cell Immunol. 2013, 281, 44-50. [CrossRef] [PubMed]

275. Ni, L.; Fang, P.; Hu, Z.L.; Zhou, H.Y.; Chen, J.G.; Wang, F.; Jin, Y. Identification and Function of Acid-sensing Ion Channels in RAW 264.7 Macrophage Cells. Curr. Med. Sci. 2018, 38, 436-442. [CrossRef]

276. Tong, J.; Wu, W.N.; Kong, X.; Wu, P.F.; Tian, L.; Du, W.; Fang, M.; Zheng, F.; Chen, J.G.; Tan, Z.; et al. Acid-sensing ion channels contribute to the effect of acidosis on the function of dendritic cells. J. Immunol. 2011, 186, 3686-3692. [CrossRef]

277. Bautista, D.M.; Hoth, M.; Lewis, R.S. Enhancement of calcium signalling dynamics and stability by delayed modulation of the plasma-membrane calcium-ATPase in human T cells. J. Physiol. 2002, 541, 877-894. [CrossRef]

278. Ritchie, M.F.; Samakai, E.; Soboloff, J. STIM1 is required for attenuation of PMCA-mediated Ca ${ }^{2+}$ clearance during T-cell activation. EMBO J. 2012, 31, 1123-1133. [CrossRef] 
279. DeSantiago, J.; Batlle, D.; Khilnani, M.; Dedhia, S.; Kulczyk, J.; Duque, R.; Ruiz, J.; Pena-Rasgado, C.; Rasgado-Flores, H. $\mathrm{Ca}^{2+} / \mathrm{H}+$ exchange via the plasma membrane $\mathrm{Ca}^{2+}$ ATPase in skeletal muscle. Front. Biosci. 2007, 12, 4641-4660. [CrossRef]

280. Milanick, M.A. Proton fluxes associated with the Ca pump in human red blood cells. Am. J. Physiol. 1990, 258, C552-C562. [CrossRef]

281. Payen, V.L.; Mina, E.; Van Hee, V.F.; Porporato, P.E.; Sonveaux, P. Monocarboxylate transporters in cancer. Mol. Metab 2020, 33, 48-66. [CrossRef]

282. Rai, G.; Brimacombe, K.R.; Mott, B.T.; Urban, D.J.; Hu, X.; Yang, S.M.; Lee, T.D.; Cheff, D.M.; Kouznetsova, J.; Benavides, G.A.; et al. Discovery and Optimization of Potent, Cell-Active Pyrazole-Based Inhibitors of Lactate Dehydrogenase (LDH). J. Med. Chem. 2017, 60, 9184-9204. [CrossRef] [PubMed]

283. Serganova, I.; Cohen, I.J.; Vemuri, K.; Shindo, M.; Maeda, M.; Mane, M.; Moroz, E.; Khanin, R.; Satagopan, J.; Koutcher, J.A.; et al. LDH-A regulates the tumor microenvironment via HIF-signaling and modulates the immune response. PLoS ONE 2018, 13, e0203965. [CrossRef] [PubMed]

284. Wigerup, C.; Pahlman, S.; Bexell, D. Therapeutic targeting of hypoxia and hypoxia-inducible factors in cancer. Pharmacol. Ther. 2016, 164, 152-169. [CrossRef] [PubMed]

285. Renner, K.; Bruss, C.; Schnell, A.; Koehl, G.; Becker, H.M.; Fante, M.; Menevse, A.N.; Kauer, N.; Blazquez, R.; Hacker, L.; et al. Restricting Glycolysis Preserves T Cell Effector Functions and Augments Checkpoint Therapy. Cell Rep. 2019, 29, 135-150.e9. [CrossRef] [PubMed]

(C) 2020 by the authors. Licensee MDPI, Basel, Switzerland. This article is an open access article distributed under the terms and conditions of the Creative Commons Attribution (CC BY) license (http://creativecommons.org/licenses/by/4.0/). 